\title{
. \\ Melittin-Based Nano-Delivery Systems for Cancer Therapy
}

\author{
Anqi Wang, Yuan Zheng, Wanxin Zhu, Liuxin Yang, Yang Yang and Jinliang Peng *
}

\author{
School of Pharmacy, Shanghai Jiao Tong University, Shanghai 200240, China; wanganqi_5227@sjtu.edu.cn (A.W.); \\ zhengyuanz@163.com (Y.Z.); isamuel@sjtu.edu.cn (W.Z.); yanglx_12@126.com (L.Y.); \\ yangyang023@sjtu.edu.cn (Y.Y.) \\ * Correspondence: pj176@sjtu.edu.cn
}

Citation: Wang, A.; Zheng, Y.; Zhu, W.; Yang, L.; Yang, Y.; Peng, J.

Melittin-Based Nano-Delivery

Systems for Cancer Therapy.

Biomolecules 2022, 12, 118. https://

doi.org/10.3390/biom12010118

Academic Editor: Bahman Anvari

Received: 25 November 2021

Accepted: 4 January 2022

Published: 12 January 2022

Publisher's Note: MDPI stays neutral with regard to jurisdictional claims in published maps and institutional affiliations.

Copyright: (c) 2022 by the authors Licensee MDPI, Basel, Switzerland. This article is an open access article distributed under the terms and conditions of the Creative Commons Attribution (CC BY) license (https:// creativecommons.org/licenses/by/ $4.0 /)$.

\begin{abstract}
Melittin (MEL) is a 26-amino acid polypeptide with a variety of pharmacological and toxicological effects, which include strong surface activity on cell lipid membranes, hemolytic activity, and potential anti-tumor properties. However, the clinical application of melittin is restricted due to its severe hemolytic activity. Different nanocarrier systems have been developed to achieve stable loading, side effects shielding, and tumor-targeted delivery, such as liposomes, cationic polymers, lipodisks, etc. In addition, MEL can be modified on nano drugs as a non-selective cytolytic peptide to enhance cellular uptake and endosomal/lysosomal escape. In this review, we discuss recent advances in MEL's nano-delivery systems and MEL-modified nano drug carriers for cancer therapy.
\end{abstract}

Keywords: melittin; hemolysis; stable loading; nano-delivery system; tumor therapy

\section{Introduction}

MEL is a major component of honeybee (Apis mellifera) venom with various biological and pharmacological properties [1]. Its strong surface activity on lipid membranes, anti-microbial, anti-inflammatory, and anti-cancer properties has been widely studied and proved. However, the use and application of MEL in clinical experiments is hindered because of its intense toxic side effects. Multiple strategies have been adopted and optimized to develop a safe and stable MEL delivery system. This review focusses on the recent progress of MEL carriers and drug delivery systems with MEL as a functional molecule in cancer therapy. Measures to lower the side effects of MEL are also discussed, along with the improvements and challenges relevant to each strategy.

\subsection{Structure of Melittin (MEL) and Its Interactions with Membrane}

MEL was originally isolated and purified from bee venom (BV), and is the main active ingredient in BV, accounting for approximately $50 \%$ of its dry weight [1]. Briefly, MEL has been fractionated and isolated from BV through gel filtration, high-performance liquid chromatography (HPLC), or capillary electrophoresis (CE), and analyzed by ultraviolet assay, reverse-phase HPLC and amino acid analysis [2,3]. This 26-amino peptide (Figure 1) is sequenced as follows: Gly Ile-Gly Ala-Val-Leu-Lys-Val-Leu-Thr-Thr-Gly LeuPro-Ala-Leu-Ile-Ser-Trp-Ile-Lys-Arg-Lys-Arg-Gln-GlnNH2 [4]. Its N-terminal region is hydrophobic, and its C-terminal region is hydrophilic because of the presence of positively charged amino acids [5], which carry a net charge of +6 at physiological $\mathrm{pH}$, leading to its amphiphilic property. Under natural conditions, MEL is in a tetrameric state and dissociates into monomers during ion intensity change [6,7]. The $\alpha$-helix of MEL is an essential structure that produces its lytic effects. Under different physiological conditions, the $\alpha$-helix forms a perpendicular or parallel conformation to the membrane surface. When anchored parallel to the membrane surface, the MEL molecule is inactive, and this inserting form prevents other peptides from inserting into the lipid bilayer. In the other case, MEL is inserted perpendicularly into the lipid bilayer and causes pore formation and membrane rupture, leading to the leakage of hemoglobin or other intracellular contents [8,9]. However, 
the specific mechanism of MEL and cell membrane remains controversial, as one study pointed out that the amphiphilic $\alpha$-helix structure is formed after MEL insertion to cell membrane [10].

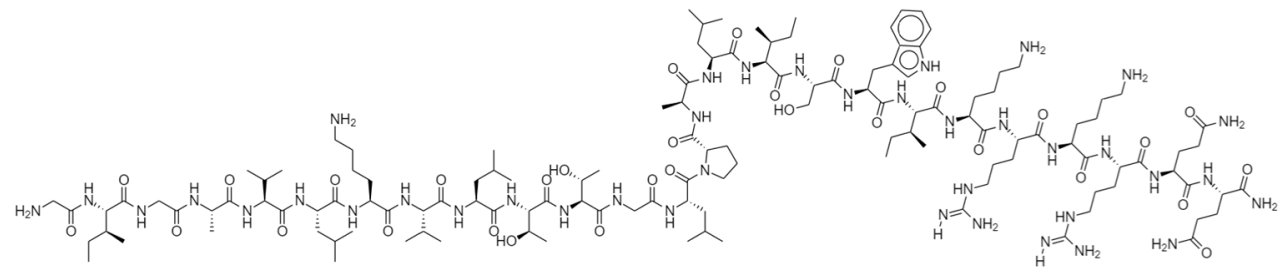

Figure 1. Chemical structure of MEL.

\subsection{Pharmacological Effect of $M E L$}

In addition to its strong surface activity on cell lipid membranes and hemolytic activity [11], MEL has tremendous biological and pharmacological effects, including antibacterial [12], anti-virus [13], anti-fungal [14,15] (Table 1), anti-inflammatory [16], and anti-tumor properties [4] (Table 2).

Table 1. In vitro anti-microbial effects of MEL.

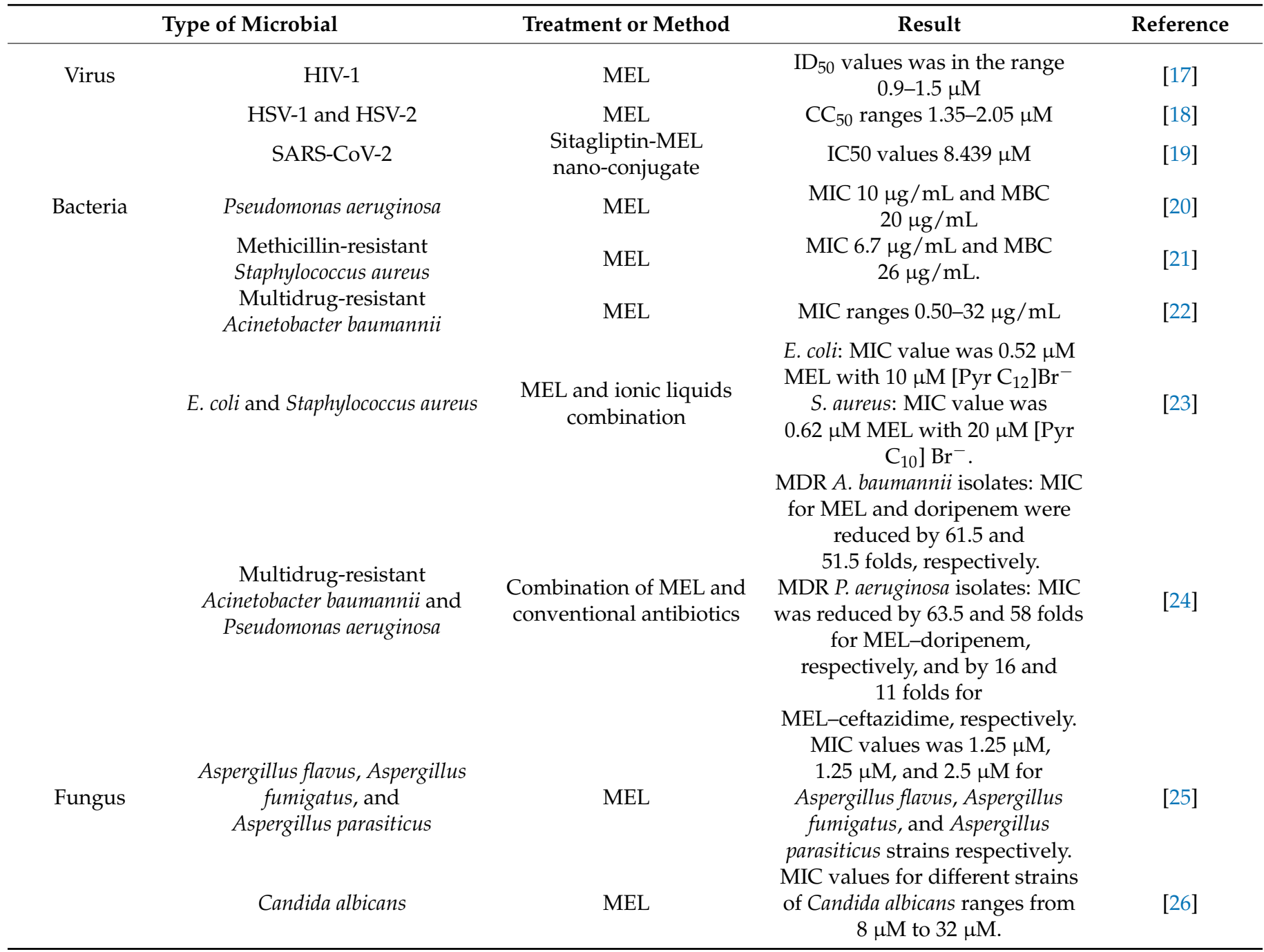


The anti-microbial effects of bee venom (BV) and MEL have been reported since the 1940s [27]. With growing concerns regarding drug-resistant bacteria, MEL has become a promising efficacious agent due to its properties of pore formation and bacterial destruction [28]. Evidence has confirmed the anti-bacterial effect of MEL, especially against drug-resistant bacteria that conventional antibiotics fail to inhibit or kill [20,24]. The combination of MEL with other antibiotics is widely evaluated [23,29]. One study evaluated MEL against methicillin-resistant Staphylococcus aureus (MRSA) strains [21] and reported a minimum inhibitory concentration (MIC) and minimum bactericidal concentration (MBC) of 6.7 and $26 \mu \mathrm{g} / \mathrm{mL}$, respectively. Meanwhile, the MIC and MBC values for oxacillin were both $32 \mu \mathrm{g} / \mathrm{mL}$. MEL in combination with oxacillin also showed synergistic results on MRSA strains.

MEL can also inhibit various viruses [13,30], including human immunodeficiency virus (HIV) [17,31], herpes simplex virus (HSV) [32,33], and respiratory syncytial virus (RSV) [13]. Its mechanism may include suppressing the gene expression of virus and impeding the multiplication process $[17,18]$. As an antiviral peptide, MEL is also a potential candidate against severe acute respiratory syndrome coronavirus 2 (SARS-CoV-2) [34,35]; a survey in beekeepers revealed the potential preventive effect of BV on coronavirus disease 2019 (COVID-19) [36]. A Sitagliptin (SIT)-MEL nano-conjugate was developed [19], and showed better antiviral potential against SARS-CoV-2 isolates than SIT and MEL alone, thus proving MEL to be one of the promising candidates.

In traditional medicine, BV has been used in the treatment of inflammatory-related illnesses [37]. MEL binds non-competitively with phospholipase A2 (PLA2) to inhibit its enzymatic activity, and thus can be used for the treatment of inflammation caused by the production or enhanced activity of secreted PLA2 [38]. MEL also has inhibitory effects on sodium nitroprusside, IKB kinase (IKK) activity, nitric oxide (NO), inducible NO synthase (iNOS), cyclooxygenase-2 (COX-2), and other inflammatory mediators due to its high binding affinity with IKKs [39], which suppresses IKB degradation and thereby blocks the nuclear factor kappa-light-chain-enhancer of the activated B cells (NF- $\kappa \mathrm{B})$ signaling pathway. MEL can inhibit the signaling pathways of toll-like receptor 2 (TLR2), TLR4, CD14, NF-кB essential modulator (NEMO), and platelet-derived growth factor receptor beta (PDGFR $\beta$ ) [40-43], consequently reducing the activation of p38 mitogen-activated protein kinases, extracellular signal-regulated protein kinase (ERK1/2), protein kinase $B$ (Akt), phospholipase C, gamma 1 (PLC $\gamma 1$ ) and the transport of NF- $k B$ into the nucleus. This inhibitory effect can also reduce inflammation of the skin, aorta, joints, liver, and neuronal tissues $[16,44]$.

\subsection{Anti-Tumor Effects of MEL}

Given that MEL attacks lipid membranes and leads to substantial cytotoxicity, it has been widely studied in anti-tumor treatments (Table 2).

Table 2. Anti-tumor effects of MEL.

\begin{tabular}{|c|c|c|c|c|}
\hline Tumor Type & Cell Lines & Treatment & Result or Mechanism & Reference \\
\hline Lung cancer & A549 and NCI-H460 cell & MEL & $\begin{array}{c}\mathrm{IC}_{50} \text { values were } 2 \mu \mathrm{g} / \mathrm{mL}, \\
3 \mu \mathrm{g} / \mathrm{mL} \text {, respectively }\end{array}$ & [45] \\
\hline \multirow{4}{*}{$\begin{array}{l}\text { Hepatocellular } \\
\text { carcinoma }\end{array}$} & A549 cell & $\begin{array}{l}\text { Antinucleolin } \\
\text { aptamer-MEL conjugate }\end{array}$ & $\begin{array}{l}\text { Viability for A549 cells after } \\
\text { treatment was } 51.2 \pm 3.5 \% \text {, }\end{array}$ & [46] \\
\hline & SMMC-7721 cells & MEL & $\begin{array}{l}\text { MEL inhibits G0/G1 cell cycle } \\
\text { progression by down-regulating }\end{array}$ & [47] \\
\hline & & & MeCP2 through Shh signaling. & \\
\hline & HepG2 cells & MEL & $\begin{array}{l}\text { HDAC2-mediated PTEN } \\
\text { upregulation, Akt inactivation, } \\
\text { and inhibition of PI3K/Akt } \\
\text { signaling pathways. }\end{array}$ & [48] \\
\hline
\end{tabular}


Table 2. Cont.

\begin{tabular}{|c|c|c|c|c|}
\hline Tumor Type & Cell Lines & Treatment & Result or Mechanism & Reference \\
\hline & $\begin{array}{l}\text { SMMC-7721 and } \\
\text { BEL-7402 cells }\end{array}$ & MEL & $\begin{array}{l}\text { MEL sensitizes human } \\
\text { hepatocellular carcinoma cells to } \\
\text { tumor necrosis factor-related } \\
\text { apoptosis-inducing ligand } \\
\text { (TRAIL)-induced apoptosis by } \\
\text { activating CaMKII-TAK1-JNK/p38 } \\
\text { and inhibiting IKB } \alpha \text { kinase-NFkB. } \\
\text { MEL inhibits the EGF-induced }\end{array}$ & [49] \\
\hline Breast cancer & MDA-MB-231 cells & MEL & $\begin{array}{l}\text { MMP-9 expression via blocking } \\
\text { the NF-KB and }\end{array}$ & {$[50]$} \\
\hline & SUM159 and SKBR3 & BV or MEL & $\begin{array}{l}\text { PI3K/Akt/mTOR pathway } \\
\text { MEL reduces the level of the PD-L1 } \\
\text { immune-checkpoint protein and } \\
\text { the immune-suppressive effects of } \\
\text { the tumor microenvironment. } \\
\mathrm{IC}_{50} \text { values for MEL was } \\
4.24 \mathrm{ng} / \mu \mathrm{L} \text { for SUM159 and } \\
3.59 \mathrm{ng} / \mu \mathrm{L} \text { for SKBR3. }\end{array}$ & [51] \\
\hline Prostate cancer & $\begin{array}{l}\text { LNCaP, DU145, and } \\
\text { PC-3 cells }\end{array}$ & BV or MEL & $\begin{array}{l}\text { MEL induces cell apoptosis by } \\
\text { activating the caspase pathway via } \\
\text { NF- } \mathrm{B} \text { inactivation. } \\
\mathrm{IC}_{50} \text { for LNCaP cells: MEL } 2.9 \text { and } \\
\text { BV } 14.2 \mu \mathrm{g} / \mathrm{mL} \text {, DU145 cells: MEL } \\
1.5 \text { and BV } 6.3 \mu \mathrm{g} / \mathrm{mL} \\
\mathrm{IC}_{50} \text { for PC-3 cells: MEL } 1.8 \text { and } \\
\text { BV } 6.1 \mu \mathrm{g} / \mathrm{mL} \text {, respectively }\end{array}$ & [52] \\
\hline Leukemia & $\begin{array}{l}\text { CCRF-CEM and } \\
\text { K-562 cells }\end{array}$ & MEL & $\begin{array}{l}\text { MEL induces apoptosis via the } \\
\text { intrinsic/mitochondrial pathway. }\end{array}$ & [53] \\
\hline
\end{tabular}

BV suppresses COX-2 mRNA expression and PGE 2 synthesis; hence, MEL may also exert anti-tumor effects [54]. MEL inhibits proliferation of the cancer cells via induction of apoptosis through multiple investigated mechanisms. One possible mechanism is that MEL causes changes in the permeability of cell membranes, which leads to the elevation of intracellular $\mathrm{Ca}^{2+}$, an important regulator in the apoptosis process, and activation of PLA2 [55], resulting in cell death. MEL presents a significant anti-tumor effect through the NF- $\kappa B$ pathway, which is involved in multiple physiological processes including tumor [56]. Its other mechanism of apoptosis includes decreasing methyl-CpG binding protein 2 [47] and PI3K/Akt/mTOR signaling pathway $[48,50]$.

MEL also inhibits the invasion and metastasis of cancer cells. MEL prevents hepatocellular carcinoma cell metastasis via inhibition of ras-related $\mathrm{C} 3$ botulinum toxin substrate 1 (Rac1) [57], which participates in the c-Jun N-terminal kinase (JNK) and JNK-dependent cell motility processes and induces metastasis. In addition, MEL selectively inhibits expression of matrix metalloproteinase-9 (MMP-9), which plays an important role in the migration of cancer cells $[50,58,59]$ via down-regulating activator protein-1 (AP-1) and NF- $\mathrm{kB}$ expression.

\subsection{Obstacles to the Applications of MEL}

Despite its multiple pharmacological potentials, the clinical applications of MEL are limited due to its strong surface activity and cytotoxicity. MEL results in 50\% hemolysis of human red blood cells at $2 \mu \mathrm{M}$ concentration and $100 \%$ at $7 \mu \mathrm{M}$ [60]. Studies examining the antimicrobial activity of MEL in vivo [61] have found an increased mortality rate in mice directly injected with MEL. $\mathrm{LD}_{50}$ value of intraperitoneal MEL to mice is around $5 \mathrm{mg} / \mathrm{kg}$, and drops to about $3 \mathrm{mg} / \mathrm{kg}$ via intravenous injection [62-64]. Preclinical and clinical research on BV therapy has indicated that the main adverse reactions of MEL include allergic reactions and pain at the administration site $[65,66]$, which limits BV's application in acupuncture therapies. Further applications of MEL are also restricted due to its degradability [67], low bioavailability [68], and non-specific lytic effects. 
Multiple strategies have been applied to stably and safely load MEL to obtain effective anti-tumor as well as other therapeutic effects. The designated purposes of MEL delivery systems are approximately the same. Other than increasing the delivery efficiency of MEL, delivery systems conceal MEL to prevent it from interacting with cell membranes as well as to mask its positive charge so as not to bind to other proteins in vivo. Additionally, delivery systems enable targeting delivery to the lesion areas via the enhanced permeability and retention (EPR) effect or stimulus responsive designs. With surface activity and affinity for lipid membranes, MEL is also applied in drug delivery system to enhance cell uptake and endosomal escape (Figure 2).

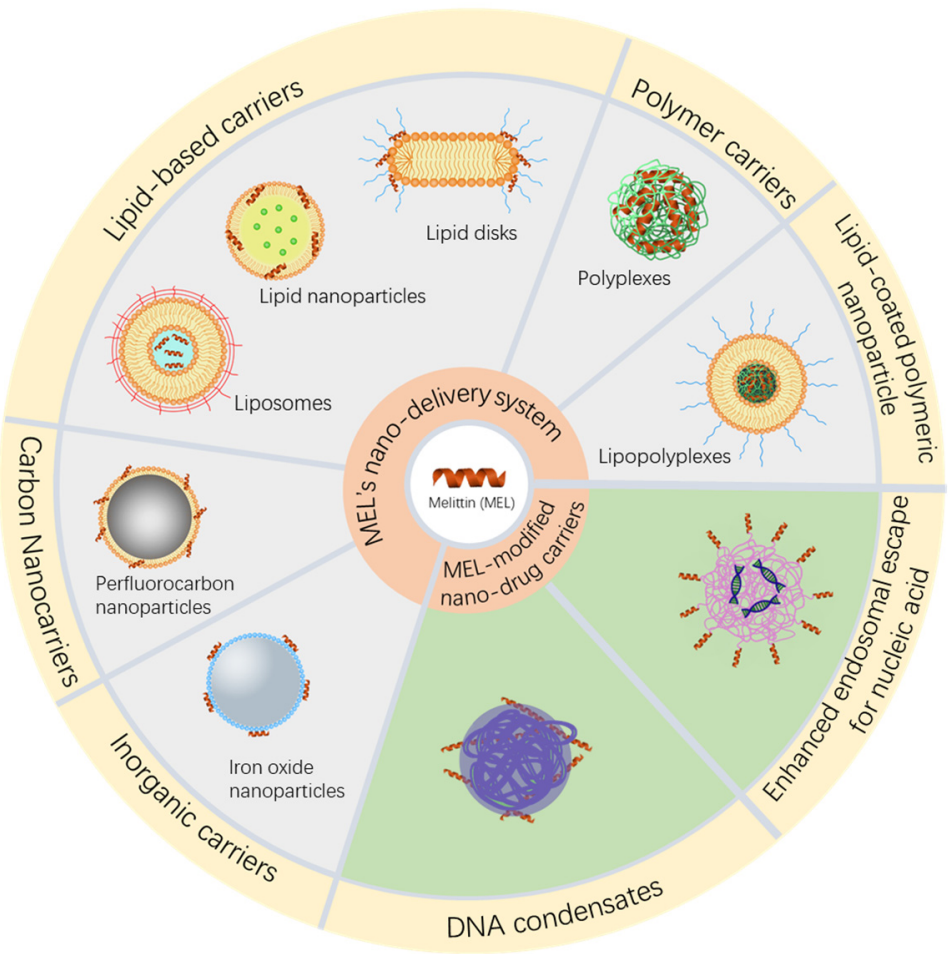

Figure 2. Strategies of MEL nano-delivery systems and MEL-modified nucleic acid nanocarriers for cancer therapy.

\section{Delivery Vehicles for Melittin}

The following two main strategies are adopted to overcome the cytotoxicity and hemolysis effects of MEL: incorporating nanoparticles that can safely deliver a substantial amount of MEL through the intravenous route, and modifying MEL to reduce its toxicity.

\subsection{Modified MEL and Conjugates}

Changing the amino acid sequence of MEL or linking it with polypeptides or other molecules provides it with certain properties, such as in vivo stability or targeting. The hemolysis of MEL decreases after phosphorylation [69] or modification of amino acid sequences to obtain MEL analogs [70,71] has been proved. The derived MEL peptides have been designed and developed to exert more desirable properties, such as lower hemolysis effects [72-74], enhanced therapeutic properties [75,76] and even controllable activation providing targeting ability to tumor tissue [70,77]. Substituting alanine for leucine drastically reduces the hemolytic activity on human red blood cells, which is only about $1-2 \%$ of the hemolytic activity of MEL, while the antibacterial activity remains equivalent to MEL [73]. Meanwhile, modifications on the C-terminal region (R22A, K23A, $\mathrm{R} 24 \mathrm{Q})$ reduce the net charge of the protein and increase its pore-forming ability (20-fold more potent than MEL) [78]. 
In one study of MEL conjugate development, 2,3-dimethylmaleic anhydride (DMMA) was used to modify the active amino groups in MEL to obtain ultra $\mathrm{pH}$ sensitivity [79]. DMMA concealed the original positive charge of MEL and significantly reduced the hemolysis and clearance of reticulo-endothelial system. Other modification methods include immunoconjugates $[46,80]$ and hybrid peptides [81]. MEL covalently links to the antinucleolar protein aptamer AS1411 and forms a conjugate that can achieve targeted delivery to multiple cancer cells. Compared with free MEL, this modified MEL has significantly reduced hemolytic activity and greater cytotoxicity in A549 cells [46]. The bacteria-killing efficacy of MEL is improved after being decorated on graphene (Gra) or graphene oxide (GO) nanosheets, which increase its ability to permeate the cell membrane and cause rapid bacterial leakage [82].

\subsection{Nano Delivery Vehicles}

Nano drug delivery systems have been widely applied in MEL delivery. Attempts such as inorganic carriers (including quantum dots, $\mathrm{Fe}_{3} \mathrm{O}_{4}$ nanoparticles, and perfluorocarbon nanoparticles), polymer carriers (including PLGA nanoparticles and $\beta$-cyclodextrin nanoparticles), and lipid carriers (including lipid disks, lipid nanoparticles, MEL-lipid conjugate nanoparticles and liposomes) greatly reduce the toxicity of MEL and provide the possibility of targeting to the intended sites (Table 3).

Table 3. Summary of MEL-loading nano-delivery systems and applications.

\begin{tabular}{|c|c|c|c|c|}
\hline Type & Loading Strategy & Size & Applications & Reference \\
\hline Quantum dots & $\begin{array}{l}\text { MEL was modified to CdSe/ZnS } \\
\text { core quantum dots }\end{array}$ & $5-10 \mathrm{~nm}$ & $\begin{array}{l}\text { Quantum dots were used to study the } \\
\text { interaction between protein and membrane, } \\
\text { and had potential to deliver MEL in vivo. }\end{array}$ & [83] \\
\hline $\begin{array}{c}\text { Iron oxide } \\
\text { nanoparticles }\end{array}$ & $\begin{array}{c}\text { MEL and doxorubicin (DOX) were } \\
\text { co-loaded to citric } \\
\text { acid-functionalized } \mathrm{Fe}_{3} \mathrm{O}_{4} \\
\text { magnetic nanoparticles } \\
\text { (CA-MNPs) }\end{array}$ & $20 \mathrm{~nm}$ & $\begin{array}{l}\text { The release of both MEL and DOX was } \\
\text { strongly enhanced at } \mathrm{pH} 4.5 \text { and the } \\
\text { nanoparticles were potentially applied in } \\
\text { magnetically targeted cancer therapy. }\end{array}$ & [84] \\
\hline $\begin{array}{l}\text { Perfluorocarbon (PFC) } \\
\text { nanoparticles }\end{array}$ & $\begin{array}{l}\text { MEL was added to the } \\
\text { PFC nanoparticles }\end{array}$ & $\sim 290 \mathrm{~nm}$ & $\begin{array}{l}\text { PFC nanoparticles retained their structural } \\
\text { integrity after the addition and contribute } \\
\text { to the stability and slow dissociation of } \\
\text { MEL from the stabilizing monolayer. }\end{array}$ & [85] \\
\hline \multirow{5}{*}{$\begin{array}{l}\text { Poly (D,L-lactic } \\
\text { acid-coglycolic acid) } \\
\text { (PLGA) nanoparticles }\end{array}$} & $\begin{array}{l}\text { MEL was mixed and incubated } \\
\text { with PFC nanoparticles }\end{array}$ & $227 \mathrm{~nm}$ & $\begin{array}{l}\text { The growth of the tumors was inhibited by } \\
24.68 \% \text { in MDA-MB- } 435 \text { human } \\
\text { breast cancer. }\end{array}$ & [86] \\
\hline & $\begin{array}{c}\text { MEL derivative peptide was } \\
\text { incubated with PFC nanoparticles } \\
\text { composed of egg } \\
\text { phosphatidylcholineand } \\
\text { dipalmitoylphosphatidylglycerol }\end{array}$ & $\sim 280 \mathrm{~nm}$ & $\begin{array}{l}\text { This MEL derivative is activated by matrix } \\
\text { metalloproteinase-9 (MMP-9), a protease } \\
\text { overexpressed in many tumor cells. In } \\
\text { addition, treatment of PFC nanoparticles } \\
\text { resulted in } \sim 54 \% \text { reduction in melanoma } \\
\text { tumor size in vivo. }\end{array}$ & [70] \\
\hline & $\begin{array}{l}\text { BV-loaded PLGA/ } \\
\text { PVA nanoparticles }\end{array}$ & $180 \mathrm{~nm}$ & $\begin{array}{l}\text { PLGA nanoparticles reduced side effects by } \\
\text { slowing down BV release, and prolonged } \\
\text { suppression of nociceptive behavior in rats } \\
\text { with formalin-induced pain. }\end{array}$ & [87] \\
\hline & $\begin{array}{l}\text { MEL was modified with sodium } \\
\text { dodecyl sulfate and then } \\
\text { formulated into } \\
\text { PLGA nanoparticles }\end{array}$ & $\sim 130 \mathrm{~nm}$ & $\begin{array}{l}\text { MEL was loaded with a high encapsulation } \\
\text { efficiency in the nanoparticles and the } \\
\text { concentration of half the cell growth }\left(\mathrm{GI}_{50}\right) \\
\text { in breast cancer MCF-7 cells was } \\
4.42 \mu \mathrm{g} / \mathrm{mL} \text { in vitro. }\end{array}$ & [88] \\
\hline & $\begin{array}{l}\text { Tetrameric MEL binds avidly to } \\
\text { PLGA-NPs }\end{array}$ & $110 \mathrm{~nm}$ & $\begin{array}{l}\text { Biodegradable tetrameric MEL is } \\
\text { encapsulated in nanoparticles at efficiency } \\
\text { of } 97 \% \text { and retains lytic activity. }\end{array}$ & [89] \\
\hline
\end{tabular}


Table 3. Cont.

\begin{tabular}{|c|c|c|c|c|}
\hline Type & Loading Strategy & Size & Applications & Reference \\
\hline $\begin{array}{l}\beta \text {-cyclodextrin }(\beta- \\
\text { CDP) } \\
\text { nanoparticles }\end{array}$ & $\begin{array}{l}5 \text { different functional monomer } \\
\text { adamantane derivatives (Ad-Ds) } \\
\text { incubated with } \beta \text {-CDPs } \\
\text { respectively, and then mixed } \\
\text { with MEL }\end{array}$ & $30-200 \mathrm{~nm}$ & $\begin{array}{l}\text { The percentage of hemolytic toxicity } \\
\text { neutralization reached } 100 \% \text { at the } \\
\text { concentration of } 100 \mu \mathrm{M} \text {. The cytotoxicity } \\
\text { of } 30 \mu \mathrm{g} / \mathrm{mL} \text { MEL with } 2 \mathrm{mmol} / \mathrm{mL} \\
\text { nanoparticle decreased by sixfold } \\
\text { compared with that of free MEL in } \\
\text { CCRF-CEM cells. }\end{array}$ & [90] \\
\hline \multirow[t]{4}{*}{ Lipodisks } & $\begin{array}{c}\text { MEL incubated with } \\
\text { PEG-stabilized lipid disks which } \\
\text { composed of } \\
\text { POPC/cholesterol/ceramide- } \\
\text { PEG }\end{array}$ & $20-100 \mathrm{~nm}$ & $\begin{array}{l}\text { PEGylated lipodisks allowed stable } \\
\text { loading of MEL, and retained anti-bacterial } \\
\text { activity of MEL in } E \text {. coli, but extended the } \\
\text { actions by slowing down releasing rate. }\end{array}$ & [91] \\
\hline & $\begin{array}{l}\text { Lipid disks was modified by } \\
\text { c(RGDyK)-PEG } 3400-\text { DSPE }\end{array}$ & $50 \mathrm{~nm}$ & $\begin{array}{c}\text { The disks induced no hemoglobin release } \\
\text { at maximum tested concentration } \\
(100 \mu \mathrm{g} / \mathrm{mL}) \text { and presented significate } \\
\text { targeting and in vivo anti-tumor effect } \\
\text { towards U87 glioma cells. }\end{array}$ & [92] \\
\hline & $\begin{array}{l}\text { MEL loaded lipodisks contained } \\
\text { EGF-conjugated PEG-lipids. }\end{array}$ & $\sim 20 \mathrm{~nm}$ & $\begin{array}{l}\text { The EGF-targeted lipodisks binded } \\
\text { specifically to A- } 431 \text { tumor cells, and } \\
\text { resulted in a improved cell-killing effect, as } \\
\text { cell viability decreased } 20 \% \text { compared to } \\
\text { free MEL. }\end{array}$ & [93] \\
\hline & $\begin{array}{l}\text { MEL and paclitaxel were } \\
\text { co-loaded within 9G-A7R } \\
\text { modified lipodisks. }\end{array}$ & $\sim 50 \mathrm{~nm}$ & $\begin{array}{l}\text { Co-loading prevented leakage of MEL from } \\
\text { the disks and improved cytotoxicity on } \\
\text { U87 cells in vitro and anti-tumor effect in } \\
\text { intracranial glioma models. The synergistic } \\
\text { effect of MEL and paclitaxel was proved as } \\
\text { combination index values was } 0.45 \text {. }\end{array}$ & [94] \\
\hline Lipid nanoparticles & $\begin{array}{l}\text { MEL was linked to an amphipathic } \\
\text { peptide then loaded in ultrasmall } \\
\text { lipid nanoparticles }\end{array}$ & $14 \mathrm{~nm}$ & $\begin{array}{l}\text { The ultrasmall lipid nanoparticles } \\
\text { significantly reduced the hemolysis of MEL } \\
\text { and showed obvious anti-tumor effect in } \\
\text { malignant melanoma B16F10 cells, with } \\
\text { IC }_{50} \text { values being } 11.26 \mu \mathrm{M} \text {. }\end{array}$ & [81] \\
\hline $\begin{array}{l}\text { MEL-lipid conjugate } \\
\text { nanoparticles }\end{array}$ & MEL-phospholipid scaffold & $10-20 \mathrm{~nm}$ & $\begin{array}{l}\text { The nanoparticles induced tumor cell } \\
\text { apoptosis, releasing whole-tumor antigens } \\
\text { in situ, and targeting to lymph nodes. }\end{array}$ & [95] \\
\hline \multirow[t]{4}{*}{ Liposomes } & $\begin{array}{l}\text { MEL was loaded in PEGylated } \\
\text { anti-HER2 immunoliposomes } \\
\text { modified by the complete antibody } \\
\text { (trastuzumab) }\end{array}$ & $139 \mathrm{~nm}$ & $\begin{array}{l}\text { The immunoliposomes decreased cancer } \\
\text { cells viability in a dose-response manner } \\
\text { and in correlation to the level of HER2 } \\
\text { expression in human breast cancer cells. }\end{array}$ & [96] \\
\hline & $\begin{array}{l}\text { MEL loaded liposomes was } \\
\text { modified by antibodies against the } \\
\text { fish viral hemorrhagic septicemia } \\
\text { rhabdovirus (VHSV) glycoprotein } \\
\text { G (gpG) }\end{array}$ & $\sim 140 \mathrm{~nm}$ & $\begin{array}{l}\text { The in vitro antiviral studies showed that } \\
\text { the liposomes inhibited the infectivity by } \\
95.2 \% \text { through inactivating VHSV. }\end{array}$ & [97] \\
\hline & $\begin{array}{l}\text { MEL was modified with } 2 \% \\
\text { poloxamer } 188 \text { then loaded in } \\
\text { nano-liposomes. }\end{array}$ & NA & $\begin{array}{l}\text { Multiple hepatic carcinoma cell lines } \\
\text { (Bel-7402, BMMC-7721, HepG2, LM-3, and } \\
\text { Hepa 1-6 cells) were sensitive to the } \\
\text { liposomes, and the IC } 50 \text { value was close to } \\
\text { free MEL, indicating efficient } \\
\text { anti-tumor effect. }\end{array}$ & [98] \\
\hline & $\begin{array}{l}\text { Hyaluronic acid (HA) modified } \\
\text { MEL-loading liposomes }\end{array}$ & $133 \mathrm{~nm}$ & $\begin{array}{l}\text { HA enhanced the sustained-release effect } \\
\text { of MEL from the liposomes and provide } \\
\text { targeting ability via specific binding with } \\
\text { CD44, which is highly expressed on the } \\
\text { surface of melanoma B16F10 cells. }\end{array}$ & [99] \\
\hline $\begin{array}{l}\text { Lipid-coated } \\
\text { polymeric } \\
\text { Nanoparticles }\end{array}$ & $\begin{array}{c}\text { MEL and poly } \gamma \text {-glutamic acid } \\
\text { ( } \gamma \text {-PGA) formed nanoparticles } \\
\text { which then coated by cationic } \\
\text { liposomes modified by PEG and } \\
\text { DSPE-PEG-RGD }\end{array}$ & $\sim 100 \mathrm{~nm}$ & $\begin{array}{l}\text { The hemolytic activity and nonspecific } \\
\text { cytotoxicity of MEL were remarkably } \\
\text { reduced by the lipid-coated polymeric } \\
\text { nanoparticles and the RGD-modified RGD } \\
\text { modified nanoparticles effectively induced } \\
\text { apoptosis in A549 cells. }\end{array}$ & [100] \\
\hline
\end{tabular}


Table 3. Cont.

\begin{tabular}{|c|c|c|c|c|}
\hline Type & Loading Strategy & Size & Applications & Reference \\
\hline \multirow[t]{5}{*}{$\begin{array}{l}\text { Stimulus-responsive } \\
\text { delivery systems }\end{array}$} & $\begin{array}{l}\text { MEL was grafted to } \\
\text { nanodiamonds coated with } \\
\text { PEGylated PGA. }\end{array}$ & $220 \mathrm{~nm}$ & $\begin{array}{l}\text { The nanoparticles were } \mathrm{pH} \text { sensitive and } \\
\text { steady able to released MEL in an acidic } \\
\text { environment. Toxicity to breast cancer } \\
\text { MFC-7 cells was enhanced than free MEL } \\
\text { in a concentration-dependent manner. } \\
\text { The } \mathrm{pH} \text { sensitive micellar formulations }\end{array}$ & [101] \\
\hline & $\begin{array}{l}\text { D-MEL was conjugated with PEG } \\
\text { which is polymerized with } \\
\text { DIPAMA and PDSEMA, to } \\
\text { form micelles. }\end{array}$ & $33 \mathrm{~nm}$ & $\begin{array}{l}\text { unsheathes MEL only at endosomal } \mathrm{pH} \text {, } \\
\text { remarkably reducing hemolytic effects of } \\
\text { MEL, and } \mathrm{IC}_{50} \text { for the micelles in 3T3, } \\
\text { A549, CT26 cancer cells were } 8.5 \mu \mathrm{M} \text {, } \\
6.9 \mu \mathrm{M}, 11.6 \mu \mathrm{M} \text {, respectively. }\end{array}$ & [102] \\
\hline & $\begin{array}{l}\text { MEL was loaded in negatively } \\
\text { charged nanospheres consisting of } \\
\text { NIR-absorbing molecule cypate } \\
\text { and HA. }\end{array}$ & $\sim 50 \mathrm{~nm}$ & $\begin{array}{l}\text { The nanospheres responsive to both } \mathrm{pH} \\
\text { and near-infrared (NIR) laser irradiation } \\
\text { changes into net-like nanofibers and small } \\
\text { nanospheres }(\sim 25 \mathrm{~nm}) \text { when stimulated } \\
\text { and induce cancer cell death, inhibit the } \\
\text { metastatic dissemination of tumor cells, } \\
\text { and facilitated deep tumor penetration o }\end{array}$ & [103] \\
\hline & $\begin{array}{l}\text { Serum albumin (SA)-coated } \\
\text { boehmite scaffold was loaded with } \\
\text { photosensitizer chlorin e6 (Ce6) } \\
\text { and MEL. }\end{array}$ & $184 \mathrm{~nm}$ & $\begin{array}{c}\text { The nanocarrier exerted high encapsulation } \\
\text { efficiency of MEL and low } \\
\text { hemocompatibility. In vivo phototreatment } \\
\text { of the scaffold eliminated } 4 \mathrm{~T} 1 \text { cells } \\
\text { remarkably in subcutaneous breast } \\
\text { tumor models. }\end{array}$ & {$[104]$} \\
\hline & $\begin{array}{l}\text { MEL loaded in redox-sensitive } \\
\text { nanocomplexes }\end{array}$ & $357 \mathrm{~nm}$ & $\begin{array}{l}\text { The nanocomplexes decreased hemolysis } \\
\text { of MEL and released MEL responding to } \\
\text { high redox potential environment, and } \\
\text { showed an enhanced cytotoxicity on both } \\
\text { HCT } 116 \text { colon cancer cells and MCF-7 } \\
\text { breast cancer cells. }\end{array}$ & [105] \\
\hline
\end{tabular}

\subsubsection{Inorganic Carriers}

Quantum dots are small semiconductor particles (size of a few nanometers) with unique optical and electronic properties as well as potential anti-tumor and photosensitive properties [106,107]. Dang et al. [83] modified CdSe/ZnS core/shell quantum dots by using the high-affinity interaction between phosphorylcholine and MEL. A fluorescence resonance energy transfer (FRET) system was formed between the Cy3b label on MEL and the quantum dots. This system was used to study the interaction between protein and membrane, and has potential applications in cancer therapy. The tumor-targeting and anti-tumor effects of quantum dots were demonstrated in lung cancer $[108,109]$ and pancreatic cancer cells [110]. However, it is only in primary stage and cannot stably carry MEL for a long time to avoid MEL hemolysis.

Studies have proved the feasibility of loading MEL on inorganic metal nanoparticles such as iron oxide [111,112] and gold nanoparticles [113,114]. Hematyar et al. [84] developed a magnetic-responsive co-delivery system for effective cancer therapy. Doxorubicin (DOX) and MEL were loaded onto the surface of citric acid-functionalized $\mathrm{Fe}_{3} \mathrm{O}_{4}$ magnetic nanoparticles (CA-MNPs) through electrostatic interaction. CA-MNPs possess superparamagnetic nature and have potential to be directed and localized to tumor targets by external magnetic fields. The advantage of metal nanoparticles as MEL vectors is that several metal materials possess stimulus-responsive ability, which enhances targeting transportation of MEL, while some metal-based (gold or silver) nanoparticles have been proven to exert anti-cancer effects [115], and may obtain a better therapeutic effect in combination with MEL.

\subsubsection{Carbon Nanocarriers}

Perfluorocarbon (PFC) nanoparticles are composed of a hydrophobic PFC core surrounded by a phospholipid monolayer where MEL can be stably inserted into the phospholipid monolayer without destroying the nanoparticle structure $[70,85,116]$. The toxicity 
of MEL to sperm and vaginal epithelial cells is reduced fivefold when delivered in PFC nanoparticles; to some extent, this characteristic guarantees the safety of MEL as an antiHIV agent [116]. PFC nanoparticles extends the half-life of MEL in plasma from 24 min to more than $300 \mathrm{~min}$ and improves safety by promoting the clearance of circulating peptides through the reticuloendothelial system [86]. However, the PFC-containing MEL nanoformulation has a large particle size $(250 \sim 300 \mathrm{~nm})$, which may not be conducive to diffusion and cellular uptake on sites [117].

\subsubsection{Polymer Carriers}

Poly (D, L-lactic acid-co-glycolic acid) (PLGA) is a common biodegradable polyester that can carry MEL in nanoparticles [87-89,118]. Yang et al. [88] paired MEL with the anionic agent sodium lauryl sulfate. The formed complex was highly soluble in organic solvents and formulated into MEL-PLGA nanoparticles, resulting in improved drug loading efficiency $(\sim 90 \%)$ and drug content $(6-7 \%)$. The in vivo experimental study of Jeong et al. [87] on PLGA-coated BV preparations for pain inhibition showed that PLGA-coated MEL induced by acupuncture therapy significantly prolonged the time of pain suppression in rats and decreased the side effects by reducing the rate of release from nanoparticles. The MEL-loaded PLGA microspheres produced in high encapsulation can achieve a controlled release rate correlated with polymer degradation rate [119]. However, MEL-polymer nanoparticles formed based on charge interaction face obstacles in the stable loading of MEL under relatively complicated physiological conditions, and remain unsuitable for systemic circulation.

$\beta$-Cyclodextrin $(\beta-C D P)$, an easily available polymer material, has a ring-shaped truncated cone topology with a hydrophobic cavity to non-covalently contain diverse guest molecules [120]. Xu et al. [90] established a library of self-assembled MEL nanoparticles based on $\beta$-CDPs and functional monomer adamantane derivatives (Ad-Ds). The cytotoxicity of $30 \mu \mathrm{g} / \mathrm{mL}$ MEL with $2 \mathrm{mmol} / \mathrm{mL}$ nanoparticle decreased by sixfold compared with that of free MEL.

\subsubsection{Lipid-Based Carriers}

Lipodisk (or lipid disk) is a flat circular lipid bilayer structure where PEGylated lipid forms the highly curved edges of the lipodisk. Owing to the large curvature of the edge and hydrophobic interactions, MEL has high affinity with the edge of the lipodisk that allows it to bind to the disk preferentially; the interaction between MEL and PEG chains is negligible [91,121]. Gao et al. [92] established a cyclic RGD peptide (c (RGDyK))-modified lipid disk as a MEL carrier. In vivo experiments suggested that the lipodisk loaded with MEL significantly reduced the hemolysis effect and effectively inhibited tumor growth in mice. c (RGDyK) modification of the lipodisk increases its distribution in solid tumors and its anti-cancer efficiency. Ahlgren et al. [93] reported that EGF-targeted lipodisks had high MEL-loading efficiency and improved the specificity and cytotoxicity of MEL on tumor cells. Although the co-loading of MEL and paclitaxel in lipodisks did not induce hemolysis, the lipodisks loaded with MEL alone exhibited hemolytic toxicity at high concentrations [94], which may imply that the safety of lipid disks loaded with MEL needs to be further improved.

Modified MEL can be stably loaded into lipid nanoparticles (LNP). The hemolytic properties of MEL were concealed when linked to an amphipathic peptide, and then MEL interacted with phospholipids, self-assemble into lipid nanoparticles with a size of $15 \mathrm{~nm}$ [81]. With high MEL encapsulation rate $(>80 \%)$ and neutral zeta potential, this LNP has a significant tumor inhibitory effect on melanoma cancer models, with an inhibitory rate of $82.8 \%$. Other attempts to load MEL on nanoparticles include the use of a peptide-phospholipid scaffold to form an ultrasmall (10-20 nm) MEL-lipid nanoparticle $(\alpha-$ MEL-NP) $[95,122]$ that targets lymph nodes and elicit an anti-tumor effect and immune response as a nanovaccine. $\alpha$-MEL-NPs promote the release of whole-tumor antigens in situ. On the other hand, the size of $\alpha$-MEL-NPs is optimal so that they can efficiently drain 
into lymphatic capillaries and lymph node, activating resident antigen-presenting cells [95]. As researches have proved a significant increase of affinity of MEL with positively curved lipid surfaces $[123,124]$, both lipodisks and ultrasmall lipid nanoparticles increase the drug loading efficiency and loading stability, and has improved biocompatibility.

Liposomes are closed vesicles with a bilayer structure formed when phospholipid or phospholipid-like substances are dispersed in the aqueous phase [125,126]. MEL is amphiphilic, has a positive charge, and can be loaded into the aqueous phase of liposomes [97]. However, necessary measures must be taken to overcome the interaction between MEL and lipid layer to protect the liposome membrane from this cell-penetrating peptide. The nonionic block linear copolymer poloxamer 188, is applied in the preparation of MEL liposomes to prevent leakage $[98,127]$, resulting in decreased hemolysis and MEL-induced vascular irritation. Mao et al. [98] attached poloxamer 188 to MEL in order to encapsulate MEL and form liposomes. In vitro experiments revealed that this material has a significant inhibitory effect on the survival of hepatocellular carcinoma (HCC) cells and suppresses the growth of subcutaneous and orthotopic liver cancer transplantation tumors in vivo. A recent attempt used a liposome modified with dioleoyl-phosphoethanolamine (DOPE)-coupled HA (HADOPE) to deliver MEL; the HA layer on the surface of liposome entraps MEL and prevents it from leakage [99]. However, the outer-surface modification of liposomes may exert a limited effect in preventing MEL from affecting the lipid bilayer structure of liposomes. Further improvement is needed for long-term circulation in vivo.

\subsubsection{Lipid-Coated Polymeric Nanoparticles}

With the advantages of both the liposomes and polymeric nanoparticles, lipid-coated nanosized drug delivery systems have properties such as high drug loading capacity, high stability and biocompatibility, and prolonged circulation time in vivo [128], which make them promising for targeting delivery of MEL. Ye et al. [100] prepared a nanoparticle inner core with negative charges containing MEL and poly $\gamma$-glutamic acid ( $\gamma$-PGA), an anionic polymer. The core is then coated by the cationic lipid to form liposomes, which effectively prevent the leakage of MEL. The outer shell is composed of PEG and PEGtargeting molecule (DSPE-PEG-RGD), providing stability in long-term circulation, capacity of selective binding with target tumor cells and cytolytic activity via apoptosis induction.

\subsubsection{Stimulus-Responsive Delivery Systems}

Multiple stimulus-responsive nano delivery systems have been used to deliver MEL to attenuate the cytotoxicity of MEL during systemic circulation and to achieve its targeted delivery, including pH-responsive [101-103], magnetic-responsive [84], photosensitive $[103,104]$ and redox-sensitive [105] delivery systems. The stimulus-responsive carrier maintains a stable state during circulation in the body and is stimulated and changes conformation or structure when the nanocarrier reaches the target site and releases MEL to a therapeutic concentration $[84,101,104]$. Similar to $\mathrm{pH}$-sensitive MEL, the pH-responsive polymer is converted in a lower $\mathrm{pH}$ environment and releases active MEL. Lai et al. [101] developed a nanoparticle consisting of nanodiamonds and PEGylated polyglutamic acid, which exhibited enhanced cytotoxicity towards MCF-7 cells. A near-infrared (NIR) laser irradiation responsive nanosystem can be assembled using MEL, NIR-absorbing molecule cypate, and HA [103], of which size and morphology transform successively under changes in $\mathrm{pH}$ and NIR laser irradiation.

\section{Nano Drug Delivery System with Melittin as a Functional Molecule \\ 3.1. Melittin Enables Efficient Vesicular Escape}

The entry of exogenously applied nuclear acid into the cytoplasm and its subsequent transport into the nucleus is a major cellular barrier for nonviral gene delivery vectors. A variety of strategies have been applied with the purposes of targeted delivery to the target sites and improved cellular uptake and endosome release, including polymer-or lipid-based nanoparticles [129] and liposomes [130] etc. As a cell-penetrating peptide, MEL 
can improve the cellular uptake of therapeutic compounds and the endosomal escape of nanoparticles [131,132]. With its strong surface activity, MEL can work as a penetrating peptide to promote escape from endosomes, thus increasing the bioavailability of nanoparticles [133]. Such features makes MEL popular as an oligonucleotide transfection agent [5], as the intracellular delivery of gene has always been a technical obstacle to overcome urgently [134].

The endosomal escape effect of conjugate of MEL with commonly used polymers for nucleic acid delivery has been widely verified. Transfection experiments on a variety of cell lines have shown that the transfection efficiency of MEL-PEI-luciferase DNA conjugates is up to 700-fold higher than that of controlled group (PEI-DNA conjugates) [133]. Ogris et al. [133] developed a conjugate that covalently attached MEL to poly (ethylenimine) (PEI) condensed DNA into small, discrete particles (<100 nm in diameter). Compared with $\mathrm{PEI}$, the transfection activity of this conjugate was strongly increased within a broad range of cell lines and types. The connection between MEL and polymer has also been explored. PEI and MEL binding experiment [135] showed that the conjugate connected to the Nterminal of MEL (N-mel-PEI) has a low toxicity and a high transfection efficiency, whereas the PEI bound to the C-terminal of MEL (C-mel-PEI) shows a high cytotoxicity. A possible explanation is that the hydrophobic N-terminal of C-mel-PEI is easily inserted into the cell membrane and facilitates water flow into the bilayer, leading to membrane disturbance and instability. By contrast, N-mel-PEI tends to form a parallel conformation. This speculation is not universal; a stearyl attached to the C-terminus of MEL (stearyl-rMel) shows great efficiency, and the stearyl-rMel/p53 plasmid complex exhibits high p53 expression and anti-tumor activity [136].

\subsection{Enhanced Drug Delivery of MEL as an Adjuvant}

MEL has been widely studied and combined with various polymers to develop new, efficient, and safe non-viral gene drug delivery systems. In addition, studies reveal that MEL is able to act as attractant for certain receptors, such as PLA2 [38,137], for nano drug modification.

The problem with the use of MEL as an endosomal penetrating peptide is its nonspecificity to the lipid membrane; the nanocarrier directly inserted with MEL will present a major safety risk. Therefore, MEL must be masked until it reaches the target sites. Oude Blenke et al. [138] explored the coupling of MEL to liposomes via functionalized PEG-lipids following aldehyde-hydrazide chemistry. At endosomal $\mathrm{pH}$, the acid-labile hydrazone bond hydrolyzes and releases the peptide. Similarly, MEL can be applied in the conjugates of siRNA with $\mathrm{pH}$-sensitive polymers by masking it with $\mathrm{pH}$-labile dimethylmaleic anhydride (DMMAn) [139-141], or concealing it in micellar structure consisting of $\mathrm{pH}$-sensitive poly (2-diisopropylaminoethyl methacrylate) (p (DIPAMA)) [142,143]. Another alternative strategy is to modify the peptide to reduce cytotoxicity. Changes in hemolytic activity can be achieved by MEL derivative peptides including $\mathrm{pH}$-sensitive peptides [144,145], and light-sensitive peptides [146]. Chen et al. [147] transformed MEL into a sulfhydryl polymerized peptide and incubated with plasmid DNA to obtain peptide DNA condensates. The hemolytic potency of poly MEL was efficiently covered when combined to DNA. Modified MEL peptide p5RHH (sequence VLTTGLPALISWIKRKRQQ) transfects siRNA with an $\mathrm{IC}_{50}$ as low as $25 \mathrm{nM}$ and possesses minimal cytotoxicity at the highest tested dose $(10 \mu \mathrm{M})[71,148]$. p5RHH also works as a linker inserted into nanoparticles and liposomes, and incorporates targeting ligands, imaging agents, and therapeutic drugs into particles without affecting their integrity [149].

The immune effects of MEL make it an effective adjuvant for vaccines. Owing to its ability to increase IFN- $\gamma$ and IL-1 $\beta$ and decrease IL-10, MEL was selected as suitable adjuvant candidate for Helicobacter pylori intranasal vaccine development [150]. After deletion of the last four residues of the C-terminal region, with the aim of lowering the interactions with the cell membranes, the derived MEL peptide was linked to epitopes as an adjuvant. As the vaccine is administrated through the nasal mucosa, the side effect 
of MEL is largely eliminated. Another study showed an enhanced absorption effect of MEL as a mucosal adjuvant [151]. Compared with the control group and those receiving intranasal administration of free antigen, BALB/c mice administered with $4 \mu \mathrm{g}$ of MEL and tetanus toxoid/diphtheria toxoid remarkably enhanced the antibody titers and prolonged the immune responses.

\section{Conclusions and Prospect}

MEL is a polypeptide with various pharmacological properties and has great potential in anti-inflammatory, anti-tumor, and anti-viral applications. Although pure MEL has toxicity and hemolytic properties, the use of protection or packaging greatly reduces its systemic toxicity. New strategies based on MEL can deliver drugs safely and effectively in the body. The modified peptide transduction domain and MEL-based technology are specifically designed to enhance endosomal escape and enable new nanoscale strategies to complete the arduous task of in vivo drug delivery. Upcoming designs such as stimulus responsiveness and masking are adopted in the transportation and functionalization of MEL.

However, challenges with respect to MEL-based nanodrug delivery systems still exist. Current methods cannot completely avoid the side effects of MEL, and the transfection efficiency of gene delivery systems still has room for improvement. Further understanding the mechanism of interaction of MEL with membrane and endosomal escape is crucial for the development of its delivery system.

Despite the limitations and challenges of MEL delivery systems, the development of various novel delivery strategies and clinical trials for various diseases is being undertaken to explore an ideal delivery system for MEL. The main directions of advancement are to design and synthesize modified MEL with weakened toxicity while maintaining its pharmacological effects, and to develop more stable and biocompatible delivery systems with improved targeting and controlled releasing ability. Other measures focused on MEL treatment include construction of tumor targeted gene vector containing MEL coding sequence that induced tumor cell-specific MEL expression.

Author Contributions: A.W. performed the literature research, wrote the manuscript, and prepared the tables and figures. Y.Z., W.Z., L.Y. and Y.Y. helped to perform revisions. J.P. designed, supervised and reviewed the complete manuscript. All authors have read and agreed to the published version of the manuscript.

Funding: This work was supported by the National Natural Science Foundation of China (grant nos: 81571787 and 81690262).

Institutional Review Board Statement: Not applicable.

Informed Consent Statement: Not applicable.

Conflicts of Interest: The authors declare no conflict of interest.

\section{References}

1. Habermann, E. Bee and Wasp Venoms. Science 1972, 177, 314-322. [CrossRef] [PubMed]

2. Maulet, Y.; Brodbeck, U.; Fulpius, B.W. Purification from bee venom of melittin devoid of phospholipase A2 contamination. Anal. Biochem. 1982, 127, 61-67. [CrossRef]

3. Pacáková, V.; Štulík, K.; Thi Hau, P.; Jelínek, I.; Vinš, I.; Sýkora, D. Comparison of high-performance liquid chromatography and capillary electrophoresis for the determination of some bee venom components. J. Chromatogr. A 1995, 700, 187-193. [CrossRef]

4. Chen, J.; Guan, S.M.; Sun, W.; Fu, H. Melittin, the Major Pain-Producing Substance of Bee Venom. Neurosci. Bull. 2016, 32, 265-272. [CrossRef] [PubMed]

5. Raghuraman, H.; Chattopadhyay, A. Melittin: A Membrane-active Peptide with Diverse Functions. Biosci. Rep. 2007, 27, 189-223. [CrossRef] [PubMed]

6. Hagihara, Y.; Kataoka, M.; Aimoto, S.; Goto, Y. Charge repulsion in the conformational stability of melittin. Biochemistry 1992, 31, 11908-11914. [CrossRef]

7. Bello, J.; Bello, H.R.; Granados, E. Conformation and aggregation of melittin: Dependence on pH and concentration. Biochemistry 1982, 21, 461-465. [CrossRef] [PubMed] 
8. DeGrado, W.F.; Musso, G.F.; Lieber, M.; Kaiser, E.T.; Kézdy, F.J. Kinetics and mechanism of hemolysis induced by melittin and by a synthetic melittin analogue. Biophys. J. 1982, 37, 329-338. [CrossRef]

9. Zorilă, B.; Necula, G.; Radu, M.; Bacalum, M. Melittin Induces Local Order Changes in Artificial and Biological Membranes as Revealed by Spectral Analysis of Laurdan Fluorescence. Toxins 2020, 12, 705. [CrossRef] [PubMed]

10. Constantinescu, I.; Lafleur, M. Influence of the lipid composition on the kinetics of concerted insertion and folding of melittin in bilayers. Biochim. Biophys. Acta (BBA)-Biomembr. 2004, 1667, 26-37. [CrossRef]

11. Sessa, G.; Freer, J.H.; Colacicco, G.; Weissmann, G. Interaction of a Lytic Polypeptide, Melittin, with Lipid Membrane Systems. J. Biol. Chem. 1969, 244, 3575-3582. [CrossRef]

12. Picoli, T.; Peter, C.M.; Zani, J.L.; Waller, S.B.; Lopes, M.G.; Boesche, K.N.; Vargas, G.D.Á.; Hübner, S.d.O.; Fischer, G. Melittin and its potential in the destruction and inhibition of the biofilm formation by Staphylococcus aureus, Escherichia coli and Pseudomonas aeruginosa isolated from bovine milk. Microb. Pathog. 2017, 112, 57-62. [CrossRef]

13. Uddin, M.B.; Lee, B.H.; Nikapitiya, C.; Kim, J.H.; Kim, T.H.; Lee, H.C.; Kim, C.G.; Lee, J.S.; Kim, C.J. Inhibitory effects of bee venom and its components against viruses in vitro and in vivo. J. Microbiol. 2016, 54, 853-866. [CrossRef]

14. Lee, W.; Lee, D.G. Fungicidal mechanisms of the antimicrobial peptide Bac8c. Biochim. Biophys. Acta 2015, 1848, 673-679. [CrossRef]

15. Lee, D.G.; Park, J.H.; Shin, S.Y.; Lee, S.G.; Lee, M.K.; Kim, K.L.; Hahm, K.S. Design of novel analogue peptides with potent fungicidal but low hemolytic activity based on the cecropin A-melittin hybrid structure. Biochem Mol. Biol. Int. 1997, 43, 489-498. [CrossRef]

16. Lee, G.; Bae, H. Anti-Inflammatory Applications of Melittin, a Major Component of Bee Venom: Detailed Mechanism of Action and Adverse Effects. Molecules 2016, 21, 616. [CrossRef] [PubMed]

17. Wachinger, M.; Kleinschmidt, A.; Winder, D.; von Pechmann, N.; Ludvigsen, A.; Neumann, M.; Holle, R.; Salmons, B.; Erfle, V.; Brack-Werner, R. Antimicrobial peptides melittin and cecropin inhibit replication of human immunodeficiency virus 1 by suppressing viral gene expression. J. Gen. Virol. 1998, 79, 731-740. [CrossRef] [PubMed]

18. Albiol Matanic, V.C.; Castilla, V. Antiviral activity of antimicrobial cationic peptides against Junin virus and herpes simplex virus Int. J. Antimicrob. Agents 2004, 23, 382-389. [CrossRef] [PubMed]

19. Al-Rabia, M.W.; Alhakamy, N.A.; Ahmed, O.A.A.; Eljaaly, K.; Aloafi, A.L.; Mostafa, A.; Asfour, H.Z.; Aldarmahi, A.A.; Darwish, K.M.; Ibrahim, T.S.; et al. Repurposing of Sitagliptin- Melittin Optimized Nanoformula against SARS-CoV-2: Antiviral Screening and Molecular Docking Studies. Pharmaceutics 2021, 13, 307. [CrossRef]

20. Shams Khozani, R.; Shahbazzadeh, D.; Harzandi, N.; Feizabadi, M.M.; Pooshang Bagheri, K. Kinetics Study of Antimicrobial Peptide, Melittin, in Simultaneous Biofilm Degradation and Eradication of Potent Biofilm Producing MDR Pseudomonas aeruginosa Isolates. Int. J. Pept. Res. Ther. 2019, 25, 329-338. [CrossRef]

21. Marques Pereira, A.F.; Albano, M.; Bérgamo Alves, F.C.; Murbach Teles Andrade, B.F.; Furlanetto, A.; Mores Rall, V.L.; Delazari dos Santos, L.; de Oliveira Orsi, R.; Fernandes Júnior, A. Influence of apitoxin and melittin from Apis mellifera bee on Staphylococcus aureus strains. Microb. Pathog. 2020, 141, 104011. [CrossRef]

22. Giacometti, A.; Cirioni, O.; Kamysz, W.; D’Amato, G.; Silvestri, C.; Del Prete, M.S.; Łukasiak, J.; Scalise, G. Comparative activities of cecropin A, melittin, and cecropin A-melittin peptide CA(1-7) $\mathrm{M}(2-9) \mathrm{NH} 2$ against multidrug-resistant nosocomial isolates of Acinetobacter baumannii. Peptides 2003, 24, 1315-1318. [CrossRef] [PubMed]

23. Saraswat, J.; Aldahmash, B.; AlOmar, S.Y.; Imtiyaz, K.; Rizvi, M.M.A.; Patel, R. Synergistic antimicrobial activity of N-methyl substituted pyrrolidinium-based ionic liquids and melittin against Gram-positive and Gram-negative bacteria. Appl. Microbiol. Biotechnol. 2020, 104, 10465-10479. [CrossRef]

24. Akbari, R.; Hakemi-Vala, M.; Pashaie, F.; Bevalian, P.; Hashemi, A.; Pooshang Bagheri, K. Highly Synergistic Effects of Melittin with Conventional Antibiotics Against Multidrug-Resistant Isolates of Acinetobacter baumannii and Pseudomonas aeruginosa. Microb. Drug Resist. 2019, 25, 193-202. [CrossRef]

25. Lee, J.; Hwang, J.-S.; Hwang, I.-s.; Cho, J.; Lee, E.; Kim, Y.; Lee, D.G. Coprisin-induced antifungal effects in Candida albicans correlate with apoptotic mechanisms. Free. Radic. Biol. Med. 2012, 52, 2302-2311. [CrossRef]

26. Jia, F.; Wang, J.; Peng, J.; Zhao, P.; Kong, Z.; Wang, K.; Yan, W.; Wang, R. The in vitro, in vivo antifungal activity and the action mode of Jelleine-I against Candida species. Amino Acids 2018, 50, 229-239. [CrossRef] [PubMed]

27. Schmidt-Lange, W. The germicidal effect of bee venom. Muench Med. Wochenschr 1941, 83, 935.

28. Memariani, H.; Memariani, M.; Shahidi-Dadras, M.; Nasiri, S.; Akhavan, M.M.; Moravvej, H. Melittin: From honeybees to superbugs. Appl. Microbiol. Biotechnol. 2019, 103, 3265-3276. [CrossRef]

29. Jiang, X.; Qian, K.; Liu, G.; Sun, L.; Zhou, G.; Li, J.; Fang, X.; Ge, H.; Lv, Z. Design and activity study of a melittin-thanatin hybrid peptide. AMB Express 2019, 9, 14. [CrossRef] [PubMed]

30. Memariani, H.; Memariani, M.; Moravvej, H.; Shahidi-Dadras, M. Melittin: A venom-derived peptide with promising anti-viral properties. Eur. J. Clin. Microbiol. Infect. Dis. 2020, 39, 5-17. [CrossRef] [PubMed]

31. Hood, J.L.; Jallouk, A.P.; Campbell, N.; Ratner, L.; Wickline, S.A. Cytolytic nanoparticles attenuate HIV-1 infectivity. Antivir. Ther. 2013, 18, 95-103. [CrossRef]

32. Yasin, B.; Pang, M.; Turner, J.S.; Cho, Y.; Dinh, N.N.; Waring, A.J.; Lehrer, R.I.; Wagar, E.A. Evaluation of the inactivation of infectious Herpes simplex virus by host-defense peptides. Eur. J. Clin. Microbiol. Infect. Dis. 2000, 19, 187-194. [CrossRef] [PubMed] 
33. Isaacs Charles, E.; Jia Jun, H.; Xu, W. A Lipid-Peptide Microbicide Inactivates Herpes Simplex Virus. Antimicrob. Agents Chemother. 2004, 48, 3182-3184. [CrossRef]

34. Mousavi Maleki, M.S.; Rostamian, M.; Madanchi, H. Antimicrobial peptides and other peptide-like therapeutics as promising candidates to combat SARS-CoV-2. Expert Rev. Anti-Infect. Ther. 2021, 19, 1205-1217. [CrossRef]

35. Kasozi, K.I.; Niedbała, G.; Alqarni, M.; Zirintunda, G.; Ssempijja, F.; Musinguzi, S.P.; Usman, I.M.; Matama, K.; Hetta, H.F.; Mbiydzenyuy, N.E.; et al. Bee Venom-A Potential Complementary Medicine Candidate for SARS-CoV-2 Infections. Front. Public Health 2020, 8, 755. [CrossRef]

36. Yang, W.; Hu, F.-L.; Xu, X.-F. Bee venom and SARS-CoV-2. Toxicon 2020, 181, 69-70. [CrossRef]

37. Kwon, Y.B.; Lee, J.D.; Lee, H.J.; Han, H.J.; Mar, W.C.; Kang, S.K.; Beitz, A.J.; Lee, J.H. Bee venom injection into an acupuncture point reduces arthritis associated edema and nociceptive responses. Pain 2001, 90, 271-280. [CrossRef]

38. Saini, S.S.; Peterson, J.W.; Chopra, A.K. Melittin binds to secretory phospholipase A2 and inhibits its enzymatic activity. Biochem. Biophys. Res. Commun. 1997, 238, 436-442. [CrossRef] [PubMed]

39. Park, H.J.; Son, D.J.; Lee, C.W.; Choi, M.S.; Lee, U.S.; Song, H.S.; Lee, J.M.; Hong, J.T. Melittin inhibits inflammatory target gene expression and mediator generation via interaction with IkappaB kinase. Biochem. Pharmacol. 2007, 73, 237-247. [CrossRef] [PubMed]

40. Lee, W.R.; Kim, K.H.; An, H.J.; Kim, J.Y.; Chang, Y.C.; Chung, H.; Park, Y.Y.; Lee, M.L.; Park, K.K. The protective effects of melittin on Propionibacterium acnes-induced inflammatory responses in vitro and in vivo. J. Investig. Dermatol. 2014, 134, 1922-1930. [CrossRef]

41. Han, S.M.; Kim, J.M.; Park, K.K.; Chang, Y.C.; Pak, S.C. Neuroprotective effects of melittin on hydrogen peroxide-induced apoptotic cell death in neuroblastoma SH-SY5Y cells. BMC Complement. Altern. Med. 2014, 14, 286. [CrossRef]

42. Son, D.J.; Kang, J.; Kim, T.J.; Song, H.S.; Sung, K.J.; Yun, D.Y.; Hong, J.T. Melittin, a major bioactive component of bee venom toxin, inhibits PDGF receptor beta-tyrosine phosphorylation and downstream intracellular signal transduction in rat aortic vascular smooth muscle cells. J. Toxicol. Environ. Health A 2007, 70, 1350-1355. [CrossRef] [PubMed]

43. Park, H.J.; Lee, H.J.; Choi, M.S.; Son, D.J.; Song, H.S.; Song, M.J.; Lee, J.M.; Han, S.B.; Kim, Y.; Hong, J.T. JNK pathway is involved in the inhibition of inflammatory target gene expression and NF-kappaB activation by melittin. J. Inflamm. (Lond.) 2008, 5, 7. [CrossRef] [PubMed]

44. Park, H.J.; Lee, S.H.; Son, D.J.; Oh, K.W.; Kim, K.H.; Song, H.S.; Kim, G.J.; Oh, G.T.; Yoon, D.Y.; Hong, J.T. Antiarthritic effect of bee venom: Inhibition of inflammation mediator generation by suppression of NF-kappaB through interaction with the p50 subunit. Arthritis Rheum. 2004, 50, 3504-3515. [CrossRef] [PubMed]

45. Choi, K.E.; Hwang, C.J.; Gu, S.M.; Park, M.H.; Kim, J.H.; Park, J.H.; Ahn, Y.J.; Kim, J.Y.; Song, M.J.; Song, H.S.; et al. Cancer Cell Growth Inhibitory Effect of Bee Venom via Increase of Death Receptor 3 Expression and Inactivation of NF-kappa B in NSCLC Cells. Toxins 2014, 6, 2210-2228. [CrossRef] [PubMed]

46. Rajabnejad, S.H.; Mokhtarzadeh, A.; Abnous, K.; Taghdisi, S.M.; Ramezani, M.; Razavi, B.M. Targeted delivery of melittin to cancer cells by AS1411 anti-nucleolin aptamer. Drug Dev. Ind. Pharm. 2018, 44, 982-987. [CrossRef]

47. Wu, X.; Zhao, B.; Cheng, Y.; Yang, Y.; Huang, C.; Meng, X.; Wu, B.; Zhang, L.; Lv, X.; Li, J. Melittin induces PTCH1 expression by down-regulating MeCP2 in human hepatocellular carcinoma SMMC-7721 cells. Toxicol. Appl. Pharmacol. 2015, 288, 74-83. [CrossRef]

48. Zhang, H.; Zhao, B.; Huang, C.; Meng, X.M.; Bian, E.B.; Li, J. Melittin restores PTEN expression by down-regulating HDAC2 in human hepatocelluar carcinoma HepG2 cells. PLoS ONE 2014, 9, e95520. [CrossRef]

49. Wang, C.; Chen, T.; Zhang, N.; Yang, M.; Li, B.; Lü, X.; Cao, X.; Ling, C. Melittin, a major component of bee venom, sensitizes human hepatocellular carcinoma cells to tumor necrosis factor-related apoptosis-inducing ligand (TRAIL)-induced apoptosis by activating CaMKII-TAK1-JNK/p38 and inhibiting IkappaBalpha kinase-NFkappaB. J. Biol. Chem. 2009, 284, 3804-3813. [CrossRef]

50. Jeong, Y.J.; Choi, Y.; Shin, J.M.; Cho, H.J.; Kang, J.H.; Park, K.K.; Choe, J.Y.; Bae, Y.S.; Han, S.M.; Kim, C.H.; et al. Melittin suppresses EGF-induced cell motility and invasion by inhibiting PI3K/Akt/mTOR signaling pathway in breast cancer cells. Food Chem. Toxicol. 2014, 68, 218-225. [CrossRef]

51. Duffy, C.; Sorolla, A.; Wang, E.; Golden, E.; Woodward, E.; Davern, K.; Ho, D.; Johnstone, E.; Pfleger, K.; Redfern, A.; et al. Honeybee venom and melittin suppress growth factor receptor activation in HER2-enriched and triple-negative breast cancer. NPJ Precis. Oncol. 2020, 4, 24. [CrossRef]

52. Park, M.H.; Choi, M.S.; Kwak, D.H.; Oh, K.-W.; Yoon, D.Y.; Han, S.B.; Song, H.S.; Song, M.J.; Hong, J.T. Anti-cancer effect of bee venom in prostate cancer cells through activation of caspase pathway via inactivation of NF-kB. Prostate 2011, 71, 801-812. [CrossRef]

53. Ceremuga, M.; Stela, M.; Janik, E.; Gorniak, L.; Synowiec, E.; Sliwinski, T.; Sitarek, P.; Saluk-Bijak, J.; Bijak, M. Melittin-A Natural Peptide from Bee Venom Which Induces Apoptosis in Human Leukaemia Cells. Biomolecules 2020, 10, 247. [CrossRef]

54. Jang, M.-H.; Shin, M.-C.; Lim, S.; Han, S.-M.; Park, H.-J.; Shin, I.; Lee, J.-S.; Kim, K.-A.; Kim, E.-H.; Kim, C.-J. Bee Venom Induces Apoptosis and Inhibits Expression of Cyclooxygenase-2 mRNA in Human Lung Cancer Cell Line NCI-H1299. J. Pharmacol. Sci. 2003, 91, 95-104. [CrossRef]

55. Sharma, S.V. Melittin-induced hyperactivation of phospholipase A2 activity and calcium influx in ras-transformed cells. Oncogene 1993, 8, 939-947. [PubMed] 
56. Karin, M.; Cao, Y.; Greten, F.R.; Li, Z.-W. NF-кB in cancer: From innocent bystander to major culprit. Nat. Rev. Cancer 2002, 2, 301-310. [CrossRef]

57. Liu, S.; Yu, M.; He, Y.; Xiao, L.; Wang, F.; Song, C.; Sun, S.; Ling, C.; Xu, Z. Melittin prevents liver cancer cell metastasis through inhibition of the Rac1-dependent pathway. Hepatology 2008, 47, 1964-1973. [CrossRef] [PubMed]

58. Jeong, Y.-J.; Cho, H.-J.; Whang, K.; Lee, I.-S.; Park, K.-K.; Choe, J.-Y.; Han, S.-M.; Kim, C.-H.; Chang, H.-W.; Moon, S.-K.; et al Melittin has an inhibitory effect on TNF- $\alpha$-induced migration of human aortic smooth muscle cells by blocking the MMP-9 expression. Food Chem. Toxicol. 2012, 50, 3996-4002. [CrossRef]

59. Park, J.H.; Jeong, Y.-J.; Park, K.-K.; Cho, H.-J.; Chung, I.-K.; Min, K.-S.; Kim, M.; Lee, K.-G.; Yeo, J.-H.; Park, K.-K.; et al. Melittin suppresses PMA-induced tumor cell invasion by inhibiting NF-кB and AP-1-dependent MMP-9 expression. Mol. Cells 2010, 29, 209-215. [CrossRef] [PubMed]

60. Pandey, B.K.; Ahmad, A.; Asthana, N.; Azmi, S.; Srivastava, R.M.; Srivastava, S.; Verma, R.; Vishwakarma, A.L.; Ghosh, J.K Cell-Selective Lysis by Novel Analogues of Melittin against Human Red Blood Cells and Escherichia coli. Biochemistry 2010, 49, 7920-7929. [CrossRef] [PubMed]

61. Choi, J.H.; Jang, A.Y.; Lin, S.; Lim, S.; Kim, D.; Park, K.; Han, S.M.; Yeo, J.H.; Seo, H.S. Melittin, a honeybee venomderived antimicrobial peptide, may target methicillinresistant Staphylococcus aureus. Mol. Med. Rep. 2015, 12, 6483-6490. [CrossRef]

62. Rauen, H.M.; Schriewer, H.; Ferié, F. Alkylans-alkylandum reactions. 10. Anti-alkylanting effect of bee poison, melittine and apamine. Arzneimittelforschung 1972, 22, 1921-1922.

63. Wolfgang Bücherl, E.E.B. Venomous Animals and Their Venoms: Venomous Vertebrates; Academic Press: Cambridge, MA, USA, 1971; Volume 3, pp. 157-158.

64. Askari, P.; Namaei, M.H.; Ghazvini, K.; Hosseini, M. In vitro and in vivo toxicity and antibacterial efficacy of melittin against clinical extensively drug-resistant bacteria. BMC Pharmacol. Toxicol. 2021, 22, 42. [CrossRef]

65. Park, J.H.; Yim, B.K.; Lee, J.-H.; Lee, S.; Kim, T.-H. Risk Associated with Bee Venom Therapy: A Systematic Review and Meta-Analysis. PLoS ONE 2015, 10, e0126971. [CrossRef] [PubMed]

66. Korošec, P.; Žiberna, K.; Šilar, M.; Dežman, M.; Čelesnik Smodiš, N.; Rijavec, M.; Kopač, P.; Eržen, R.; Lalek, N.; Bajrović, N.; et al Immunological and clinical factors associated with adverse systemic reactions during the build-up phase of honeybee venom immunotherapy. Clin. Exp. Allergy 2015, 45, 1579-1589. [CrossRef] [PubMed]

67. Pan, H.; Soman, N.R.; Schlesinger, P.H.; Lanza, G.M.; Wickline, S.A. Cytolytic peptide nanoparticles ('NanoBees') for cancer therapy. Wiley Interdiscip Rev. Nanomed Nanobiotechnol. 2011, 3, 318-327. [CrossRef] [PubMed]

68. Maher, S.; McClean, S. Melittin exhibits necrotic cytotoxicity in gastrointestinal cells which is attenuated by cholesterol. Biochem. Pharmacol. 2008, 75, 1104-1114. [CrossRef]

69. Resende, V.M.F.; Vasilj, A.; Santos, K.S.; Palma, M.S.; Shevchenko, A. Proteome and phosphoproteome of Africanized and European honeybee venoms. Proteomics 2013, 13, 2638-2648. [CrossRef]

70. Jallouk, A.P.; Palekar, R.U.; Marsh, J.N.; Pan, H.; Pham, C.T.N.; Schlesinger, P.H.; Wickline, S.A. Delivery of a Protease-Activated Cytolytic Peptide Prodrug by Perfluorocarbon Nanoparticles. Bioconjug. Chem. 2015, 26, 1640-1650. [CrossRef]

71. Hou, K.K.; Pan, H.; Lanza, G.M.; Wickline, S.A. Melittin derived peptides for nanoparticle based siRNA transfection. Biomaterials 2013, 34, 3110-3119. [CrossRef]

72. Hewish, D.R.; Barnham, K.J.; Werkmeister, J.A.; Kirkpatrick, A.; Bartone, N.; Liu, S.T.; Norton, R.S.; Curtain, C.; Rivetta, D.E. Structure and activity of D-Pro14 melittin. J. Protein. Chem. 2002, 21, 243-253. [CrossRef]

73. Asthana, N.; Yadav, S.P.; Ghosh, J.K. Dissection of antibacterial and toxic activity of melittin: A leucine zipper motif plays a crucial role in determining its hemolytic activity but not antibacterial activity. J. Biol. Chem. 2004, 279, 55042-55050. [CrossRef]

74. Rex, S. A Pro $\rightarrow$ Ala substitution in melittin affects self-association, membrane binding and pore-formation kinetics due to changes in structural and electrostatic properties. Biophys. Chem. 2000, 85, 209-228. [CrossRef]

75. Guha, S.; Ferrie, R.P.; Ghimire, J.; Ventura, C.R.; Wu, E.; Sun, L.; Kim, S.Y.; Wiedman, G.R.; Hristova, K.; Wimley, W.C. Applications and evolution of melittin, the quintessential membrane active peptide. Biochem. Pharmacol. 2021, 193, 114769. [CrossRef]

76. Liu, M.; Wang, H.; Liu, L.; Wang, B.; Sun, G. Melittin-MIL-2 fusion protein as a candidate for cancer immunotherapy. J. Transl. Med. 2016, 14, 155. [CrossRef] [PubMed]

77. Wiedman, G.; Kim, S.Y.; Zapata-Mercado, E.; Wimley, W.C.; Hristova, K. pH-Triggered, Macromolecule-Sized Poration of Lipid Bilayers by Synthetically Evolved Peptides. J. Am. Chem. Soc. 2017, 139, 937-945. [CrossRef]

78. Krauson, A.J.; He, J.; Wimley, W.C. Gain-of-function analogues of the pore-forming peptide melittin selected by orthogonal high-throughput screening. J. Am. Chem. Soc. 2012, 134, 12732-12741. [CrossRef] [PubMed]

79. Luo, L.; Wu, W.; Sun, D.; Dai, H.B.; Wang, Y.; Zhong, Y.; Wang, J.X.; Maruf, A.; Nurhidayah, D.; Zhang, X.J.; et al. Acid-Activated Melittin for Targeted and Safe Antitumor Therapy. Bioconjug. Chem. 2018, 29, 2936-2944. [CrossRef]

80. Shin, S.Y.; Lee, M.K.; Kim, K.L.; Hahm, K.S. Structure-antitumor and hemolytic activity relationships of synthetic peptides derived from cecropin A-magainin 2 and cecropin A-melittin hybrid peptides. J. Pept. Res. 1997, 50, 279-285. [CrossRef] [PubMed]

81. Huang, C.; Jin, H.; Qian, Y.; Qi, S.; Luo, H.; Luo, Q.; Zhang, Z. Hybrid melittin cytolytic Peptide-driven ultrasmall lipid nanoparticles block melanoma growth in vivo. ACS Nano 2013, 7, 5791-5800. [CrossRef]

82. Lu, X.; Liu, J.; Gou, L.; Li, J.; Yuan, B.; Yang, K.; Ma, Y. Designing Melittin-Graphene Hybrid Complexes for Enhanced Antibacterial Activity. Adv. Healthc. Mater. 2019, 8, 1801521. [CrossRef] 
83. Dang, Y.-Q.; Li, H.-W.; Wu, Y. Construction of a Supramolecular Förster Resonance Energy Transfer System and Its Application Based on the Interaction between Cy3-Labeled Melittin and Phosphocholine Encapsulated Quantum Dots. ACS Appl. Mater. Interfaces 2012, 4, 1267-1272. [CrossRef] [PubMed]

84. Hematyar, M.; Soleimani, M.; Es-Haghi, A.; Rezaei Mokarram, A. Synergistic co-delivery of doxorubicin and melittin using functionalized magnetic nanoparticles for cancer treatment: Loading and in vitro release study by LC-MS/MS. Artif. Cells Nanomed. Biotechnol. 2018, 46, S1226-S1235. [CrossRef]

85. Soman, N.R.; Lanza, G.M.; Heuser, J.M.; Schlesinger, P.H.; Wickline, S.A. Synthesis and Characterization of Stable Fluorocarbon Nanostructures as Drug Delivery Vehicles for Cytolytic Peptides. Nano Lett. 2008, 8, 1131-1136. [CrossRef]

86. Soman, N.R.; Baldwin, S.L.; Hu, G.; Marsh, J.N.; Lanza, G.M.; Heuser, J.E.; Arbeit, J.M.; Wickline, S.A.; Schlesinger, P.H. Molecularly targeted nanocarriers deliver the cytolytic peptide melittin specifically to tumor cells in mice, reducing tumor growth. J. Clin. Investig. 2009, 119, 2830-2842. [CrossRef] [PubMed]

87. Jeong, I.; Kim, B.-S.; Lee, H.; Lee, K.-M.; Shim, I.; Kang, S.-K.; Yin, C.-S.; Hahm, D.-H. Prolonged analgesic effect of PLGAencapsulated bee venom on formalin-induced pain in rats. Int. J. Pharm. 2009, 380, 62-66. [CrossRef] [PubMed]

88. Yang, L.; Cui, F.; Shi, K.; Cun, D.; Wang, R. Design of high payload PLGA nanoparticles containing melittin/sodium dodecyl sulfate complex by the hydrophobic ion-pairing technique. Drug Dev. Ind. Pharm. 2009, 35, 959-968. [CrossRef]

89. Gonzalez-Horta, A.; Matamoros-Acosta, A.; Chavez-Montes, A.; Castro-Rios, R.; Lara-Arias, J. Biodegradable nanoparticles loaded with tetrameric melittin: Preparation and membrane disruption evaluation. Gen. Physiol. Biophys. 2017, 36, 373-381. [CrossRef]

90. Xu, Y.; Deng, M.; Zhang, H.; Tan, S.; Li, D.; Li, S.; Luo, L.; Liao, G.; Wang, Q.; Huang, J.; et al. Selection of Affinity Reagents to Neutralize the Hemolytic Toxicity of Melittin Based on a Self-Assembled Nanoparticle Library. ACS Appl. Mater. Interfaces 2020, 12, 16040-16049. [CrossRef]

91. Zetterberg, M.M.; Reijmar, K.; Pränting, M.; Engström, Å.; Andersson, D.I.; Edwards, K. PEG-stabilized lipid disks as carriers for amphiphilic antimicrobial peptides. J. Control. Release 2011, 156, 323-328. [CrossRef]

92. Gao, J.; Xie, C.; Zhang, M.; Wei, X.; Yan, Z.; Ren, Y.; Ying, M.; Lu, W. RGD-modified lipid disks as drug carriers for tumor targeted drug delivery. Nanoscale 2016, 8, 7209-7216. [CrossRef] [PubMed]

93. Ahlgren, S.; Reijmar, K.; Edwards, K. Targeting lipodisks enable selective delivery of anticancer peptides to tumor cells. Nanomed. Nanotechnol. Biol. Med. 2017, 13, 2325-2328. [CrossRef]

94. Wang, H.; Wang, S.; Wang, R.; Wang, X.; Jiang, K.; Xie, C.; Zhan, C.; Wang, H.; Lu, W. Co-delivery of paclitaxel and melittin by glycopeptide-modified lipodisks for synergistic anti-glioma therapy. Nanoscale 2019, 11, 13069-13077. [CrossRef] [PubMed]

95. Yu, X.; Dai, Y.; Zhao, Y.; Qi, S.; Liu, L.; Lu, L.; Luo, Q.; Zhang, Z. Melittin-lipid nanoparticles target to lymph nodes and elicit a systemic anti-tumor immune response. Nat. Commun. 2020, 11, 1110. [CrossRef] [PubMed]

96. Barrajón-Catalán, E.; Menéndez-Gutiérrez, M.P.; Falco, A.; Carrato, A.; Saceda, M.; Micol, V. Selective death of human breast cancer cells by lytic immunoliposomes: Correlation with their HER2 expression level. Cancer Lett. 2010, 290, 192-203. [CrossRef] [PubMed]

97. Falco, A.; Barrajón-Catalán, E.; Menéndez-Gutiérrez, M.P.; Coll, J.; Micol, V.; Estepa, A. Melittin-loaded immunoliposomes against viral surface proteins, a new approach to antiviral therapy. Antivir. Res. 2013, 97, 218-221. [CrossRef]

98. Mao, J.; Liu, S.; Ai, M.; Wang, Z.; Wang, D.; Li, X.; Hu, K.; Gao, X.; Yang, Y. A novel melittin nano-liposome exerted excellent anti-hepatocellular carcinoma efficacy with better biological safety. J. Hematol. Oncol. 2017, 10, 71. [CrossRef]

99. Li, Y.; Ruan, S.; Wang, Z.; Feng, N.; Zhang, Y. Hyaluronic Acid Coating Reduces the Leakage of Melittin Encapsulated in Liposomes and Increases Targeted Delivery to Melanoma Cells. Pharmaceutics 2021, 13, 1235. [CrossRef] [PubMed]

100. Ye, R.; Zheng, Y.; Chen, Y.; Wei, X.; Shi, S.; Chen, Y.; Zhu, W.; Wang, A.; Yang, L.; Xu, Y.; et al. Stable Loading and Delivery of Melittin with Lipid-Coated Polymeric Nanoparticles for Effective Tumor Therapy with Negligible Systemic Toxicity. ACS Appl. Mater. Interfaces 2021, 13, 55902-55912. [CrossRef]

101. Lai, H.; Chen, F.; Lu, M.; Stenzel, M.H.; Xiao, P. Polypeptide-Grafted Nanodiamonds for Controlled Release of Melittin to Treat Breast Cancer. ACS Macro Lett. 2017, 6, 796-801. [CrossRef]

102. Lv, S.; Sylvestre, M.; Song, K.; Pun, S.H. Development of D-melittin polymeric nanoparticles for anti-cancer treatment. Biomaterials 2021, 277, 121076. [CrossRef]

103. Jia, H.-R.; Zhu, Y.-X.; Liu, X.; Pan, G.-Y.; Gao, G.; Sun, W.; Zhang, X.; Jiang, Y.-W.; Wu, F.-G. Construction of Dually Responsive Nanotransformers with Nanosphere-Nanofiber-Nanosphere Transition for Overcoming the Size Paradox of Anticancer Nanodrugs. ACS Nano 2019, 13, 11781-11792. [CrossRef]

104. Liu, H.; Hu, Y.; Sun, Y.; Wan, C.; Zhang, Z.; Dai, X.; Lin, Z.; He, Q.; Yang, Z.; Huang, P.; et al. Co-delivery of Bee Venom Melittin and a Photosensitizer with an Organic-Inorganic Hybrid Nanocarrier for Photodynamic Therapy and Immunotherapy. ACS Nano 2019, 13, 12638-12652. [CrossRef]

105. Cheng, B.; Xu, P. Redox-Sensitive Nanocomplex for Targeted Delivery of Melittin. Toxins 2020, 12, 582. [CrossRef]

106. Clapp, A.R.; Medintz, I.L.; Mauro, J.M.; Fisher, B.R.; Bawendi, M.G.; Mattoussi, H. Fluorescence Resonance Energy Transfer Between Quantum Dot Donors and Dye-Labeled Protein Acceptors. J. Am. Chem. Soc. 2004, 126, 301-310. [CrossRef]

107. Li, X.; Vinothini, K.; Ramesh, T.; Rajan, M.; Ramu, A. Combined photodynamic-chemotherapy investigation of cancer cells using carbon quantum dot-based drug carrier system. Drug Deliv. 2020, 27, 791-804. [CrossRef] [PubMed] 
108. Choi, Y.J.; Kim, Y.J.; Lee, J.W.; Lee, Y.; Lim, Y.B.; Chung, H.W. Cyto-/genotoxic effect of CdSe/ZnS quantum dots in human lung adenocarcinoma cells for potential photodynamic UV therapy applications. J. Nanosci. Nanotechnol. 2012, 12, $2160-2168$. [CrossRef]

109. Cai, X.; Luo, Y.; Zhang, W.; Du, D.; Lin, Y. pH-Sensitive ZnO Quantum Dots-Doxorubicin Nanoparticles for Lung Cancer Targeted Drug Delivery. ACS Appl. Mater. Interfaces 2016, 8, 22442-22450. [CrossRef] [PubMed]

110. He, S.J.; Cao, J.; Li, Y.S.; Yang, J.C.; Zhou, M.; Qu, C.Y.; Zhang, Y.; Shen, F.; Chen, Y.; Li, M.M.; et al. CdSe/ZnS quantum dots induce photodynamic effects and cytotoxicity in pancreatic cancer cells. World J. Gastroenterol. 2016, 22, 5012-5022. [CrossRef] [PubMed]

111. Maleki, H.; Rai, A.; Pinto, S.; Evangelista, M.; Cardoso, R.M.S.; Paulo, C.; Carvalheiro, T.; Paiva, A.; Imani, M.; Simchi, A.; et al. High Antimicrobial Activity and Low Human Cell Cytotoxicity of Core-Shell Magnetic Nanoparticles Functionalized with an Antimicrobial Peptide. ACS Appl. Mater. Interfaces 2016, 8, 11366-11378. [CrossRef]

112. Vu, H.D.; Huynh, P.T.; Ryu, J.; Kang, U.R.; Youn, S.W.; Kim, H.; Ahn, H.J.; Park, K.; Hwang, S.K.; Chang, Y.C.; et al. Melittin-loaded Iron Oxide Nanoparticles Prevent Intracranial Arterial Dolichoectasia Development through Inhibition of Macrophage-mediated Inflammation. Int. J. Biol. Sci. 2021, 17, 3818-3836. [CrossRef]

113. Rai, A.; Pinto, S.; Evangelista, M.B.; Gil, H.; Kallip, S.; Ferreira, M.G.; Ferreira, L. High-density antimicrobial peptide coating with broad activity and low cytotoxicity against human cells. Acta Biomater. 2016, 33, 64-77. [CrossRef]

114. Brand, I.; Khairalla, B. Structural changes in the model of the outer cell membrane of Gram-negative bacteria interacting with melittin: An in situ spectroelectrochemical study. Faraday Discuss. 2021, 232, 68-85. [CrossRef]

115. Chugh, H.; Sood, D.; Chandra, I.; Tomar, V.; Dhawan, G.; Chandra, R. Role of gold and silver nanoparticles in cancer nanomedicine. Artif. Cells Nanomed. Biotechnol. 2018, 46, 1210-1220. [CrossRef] [PubMed]

116. Jallouk, A.P.; Moley, K.H.; Omurtag, K.; Hu, G.; Lanza, G.M.; Wickline, S.A.; Hood, J.L. Nanoparticle incorporation of melittin reduces sperm and vaginal epithelium cytotoxicity. PLoS ONE 2014, 9, e95411. [CrossRef]

117. Cabral, H.; Matsumoto, Y.; Mizuno, K.; Chen, Q.; Murakami, M.; Kimura, M.; Terada, Y.; Kano, M.R.; Miyazono, K.; Uesaka, M.; et al. Accumulation of sub-100 nm polymeric micelles in poorly permeable tumours depends on size. Nat. Nanotechnol. 2011, 6, 815-823. [CrossRef] [PubMed]

118. Park, M.H.; Kim, J.H.; Jeon, J.W.; Park, J.K.; Lee, B.J.; Suh, G.H.; Cho, C.W. Preformulation Studies of Bee Venom for the Preparation of Bee Venom-Loaded PLGA Particles. Molecules 2015, 20, 15072-15083. [CrossRef] [PubMed]

119. Cui, F.; Cun, D.; Tao, A.; Yang, M.; Shi, K.; Zhao, M.; Guan, Y. Preparation and characterization of melittin-loaded poly (DL-lactic acid) or poly (DL-lactic-co-glycolic acid) microspheres made by the double emulsion method. J. Control. Release 2005, 107, 310-319. [CrossRef] [PubMed]

120. Zhan, W.; Wei, T.; Yu, Q.; Chen, H. Fabrication of Supramolecular Bioactive Surfaces via $\beta$-Cyclodextrin-Based Host-Guest Interactions. ACS Appl. Mater. Interfaces 2018, 10, 36585-36601. [CrossRef]

121. Lundquist, A.; Wessman, P.; Rennie, A.R.; Edwards, K. Melittin-Lipid interaction: A comparative study using liposomes, micelles and bilayerdisks. Biochim. Biophys. Acta (BBA)-Biomembr. 2008, 1778, 2210-2216. [CrossRef]

122. Zhang, Z.; Cao, W.; Jin, H.; Lovell, J.F.; Yang, M.; Ding, L.; Chen, J.; Corbin, I.; Luo, Q.; Zheng, G. Biomimetic Nanocarrier for Direct Cytosolic Drug Delivery. Angew. Chem. Int. Ed. 2009, 48, 9171-9175. [CrossRef]

123. Wessman, P.; Strömstedt, A.A.; Malmsten, M.; Edwards, K. Melittin-Lipid Bilayer Interactions and the Role of Cholesterol. Biophys. J. 2008, 95, 4324-4336. [CrossRef]

124. Wessman, P.; Morin, M.; Reijmar, K.; Edwards, K. Effect of $\alpha$-helical peptides on liposome structure: A comparative study of melittin and alamethicin. J. Colloid Interface Sci. 2010, 346, 127-135. [CrossRef] [PubMed]

125. Akbarzadeh, A.; Rezaei-Sadabady, R.; Davaran, S.; Joo, S.W.; Zarghami, N.; Hanifehpour, Y.; Samiei, M.; Kouhi, M.; Nejati-Koshki, K. Liposome: Classification, preparation, and applications. Nanoscale Res. Lett. 2013, 8, 102. [CrossRef]

126. Bozzuto, G.; Molinari, A. Liposomes as nanomedical devices. Int. J. Nanomed. 2015, 10, 975-999. [CrossRef]

127. Tian, J.L.; Ke, X.; Chen, Z.; Wang, C.J.; Zhang, Y.; Zhong, T.C. Melittin liposomes surface modified with poloxamer 188: In vitro characterization and in vivo evaluation. Pharmazie 2011, 66, 362-367.

128. Esim, O.; Hascicek, C. Lipid-Coated Nanosized Drug Delivery Systems for an Effective Cancer Therapy. Curr. Drug Deliv. 2021, 18, 147-161. [CrossRef] [PubMed]

129. Hanafy, N.A.N.; Quarta, A.; Di Corato, R.; Dini, L.; Nobile, C.; Tasco, V.; Carallo, S.; Cascione, M.; Malfettone, A.; Soukupova, J.; et al. Hybrid polymeric-protein nano-carriers (HPPNC) for targeted delivery of TGF $\beta$ inhibitors to hepatocellular carcinoma cells. J. Mater. Sci. Mater. Med. 2017, 28, 120. [CrossRef]

130. Zylberberg, C.; Gaskill, K.; Pasley, S.; Matosevic, S. Engineering liposomal nanoparticles for targeted gene therapy. Gene Ther. 2017, 24, 441-452. [CrossRef]

131. Erazo-Oliveras, A.; Muthukrishnan, N.; Baker, R.; Wang, T.-Y.; Pellois, J.-P. Improving the Endosomal Escape of Cell-Penetrating Peptides and Their Cargos: Strategies and Challenges. Pharmaceuticals 2012, 5, 1177-1209. [CrossRef] [PubMed]

132. Paray, B.A.; Ahmad, A.; Khan, J.M.; Taufiq, F.; Pathan, A.; Malik, A.; Ahmed, M.Z. The role of the multifunctional antimicrobial peptide melittin in gene delivery. Drug Discov. Today 2021, 26, 1053-1059. [CrossRef]

133. Ogris, M.; Carlisle, R.C.; Bettinger, T.; Seymour, L.W. Melittin Enables Efficient Vesicular Escape and Enhanced Nuclear Access of Nonviral Gene Delivery Vectors. J. Biol. Chem. 2001, 276, 47550-47555. [CrossRef] 
134. Overhoff, M.; Sczakiel, G. Phosphorothioate-stimulated uptake of short interfering RNA by human cells. EMBO Rep. 2005, 6, 1176-1181. [CrossRef]

135. Boeckle, S.; Wagner, E.; Ogris, M. C-versus N-terminally linked melittin-polyethylenimine conjugates: The site of linkage strongly influences activity of DNA polyplexes. J. Gene Med. 2005, 7, 1335-1347. [CrossRef]

136. Zhang, W.; Song, J.; Liang, R.; Zheng, X.; Chen, J.; Li, G.; Zhang, B.; Yan, X.; Wang, R. Stearylated Antimicrobial Peptide Melittin and Its Retro Isomer for Efficient Gene Transfection. Bioconjug. Chem. 2013, 24, 1805-1812. [CrossRef]

137. Wang, M.; Cao, R.; Zhang, L.; Yang, X.; Liu, J.; Xu, M.; Shi, Z.; Hu, Z.; Zhong, W.; Xiao, G. Remdesivir and chloroquine effectively inhibit the recently emerged novel coronavirus (2019-nCoV) in vitro. Cell Res. 2020, 30, 269-271. [CrossRef]

138. Oude Blenke, E.; Sleszynska, M.; Evers, M.J.W.; Storm, G.; Martin, N.I.; Mastrobattista, E. Strategies for the Activation and Release of the Membranolytic Peptide Melittin from Liposomes Using Endosomal pH as a Trigger. Bioconjug. Chem. 2017, 28, 574-582. [CrossRef] [PubMed]

139. Meyer, M.; Dohmen, C.; Philipp, A.; Kiener, D.; Maiwald, G.; Scheu, C.; Ogris, M.; Wagner, E. Synthesis and Biological Evaluation of a Bioresponsive and Endosomolytic siRNA-Polymer Conjugate. Mol. Pharm. 2009, 6, 752-762. [CrossRef] [PubMed]

140. Keil, T.W.M.; Baldassi, D.; Merkel, O.M. T-cell targeted pulmonary siRNA delivery for the treatment of asthma. Wiley Interdiscip. Reviews. Nanomed. Nanobiotechnol. 2020, 12, e1634. [CrossRef]

141. Meyer, M.; Zintchenko, A.; Ogris, M.; Wagner, E. A dimethylmaleic acid-melittin-polylysine conjugate with reduced toxicity, $\mathrm{pH}$-triggered endosomolytic activity and enhanced gene transfer potential. J. Gene. Med. 2007, 9, 797-805. [CrossRef] [PubMed]

142. Cheng, Y.; Yumul, R.C.; Pun, S.H. Virus-Inspired Polymer for Efficient In Vitro and In Vivo Gene Delivery. Angew. Chem. (Int. Ed. Engl. ) 2016, 55, 12013-12017. [CrossRef]

143. Feldmann, D.P.; Cheng, Y.; Kandil, R.; Xie, Y.; Mohammadi, M.; Harz, H.; Sharma, A.; Peeler, D.J.; Moszczynska, A.; Leonhardt, H.; et al. In vitro and in vivo delivery of siRNA via VIPER polymer system to lung cells. J. Control. Release 2018, 276, 50-58. [CrossRef]

144. Zhang, S.-K.; Song, J.-W.; Li, S.-B.; Gao, H.-W.; Chang, H.-Y.; Jia, L.-l.; Gong, F.; Tan, Y.-X.; Ji, S.-P. Design of pH-sensitive peptides from natural antimicrobial peptides for enhancing polyethylenimine-mediated gene transfection. J. Gene Med. 2017, 19 , e2955. [CrossRef]

145. Ahmad, A.; Ranjan, S.; Zhang, W.; Zou, J.; Pyykkö, I.; Kinnunen, P.K.J. Novel endosomolytic peptides for enhancing gene delivery in nanoparticles. Biochim. Biophys. Acta (BBA)-Biomembr. 2015, 1848, 544-553. [CrossRef] [PubMed]

146. Ventura, C.R.; Wiedman, G.R. Substituting azobenzene for proline in melittin to create photomelittin: A light-controlled membrane active peptide. Biochim. Biophys. Acta (BBA)-Biomembr. 2021, 1863, 183759. [CrossRef]

147. Chen, C.-P.; Kim, J.-s.; Steenblock, E.; Liu, D.; Rice, K.G. Gene transfer with poly-melittin peptides. Bioconjug. Chem. 2006, 17, 1057-1062. [CrossRef] [PubMed]

148. Hou, K.K.; Pan, H.; Ratner, L.; Schlesinger, P.H.; Wickline, S.A. Mechanisms of Nanoparticle-Mediated siRNA Transfection by Melittin-Derived Peptides. ACS Nano 2013, 7, 8605-8615. [CrossRef]

149. Pan, H.; Myerson, J.W.; Ivashyna, O.; Soman, N.R.; Marsh, J.N.; Hood, J.L.; Lanza, G.M.; Schlesinger, P.H.; Wickline, S.A. Lipid membrane editing with peptide cargo linkers in cells and synthetic nanostructures. FASEB J. 2010, 24, 2928-2937. [CrossRef]

150. Jafari, E.; Mahmoodi, S. Design, expression, and purification of a multi-epitope vaccine against Helicobacter Pylori based on Melittin as an adjuvant. Microb. Pathog. 2021, 157, 104970. [CrossRef]

151. Bramwell, V.W.; Somavarapu, S.; Outschoorn, I.; Alpar, H.O. Adjuvant Action of Melittin Following Intranasal Immunisation with Tetanus and Diphtheria Toxoids. J. Drug Target. 2003, 11, 525-530. [CrossRef] [PubMed] 